\title{
Vegetal and Animal Imagery in the History of Niketas Choniates
}

\author{
ANTONY LITTLEWOOD
}

In recent years various scholars have applied modern literary criticism to Byzantine literature, ${ }^{1}$ but, unlike for Classical Greek literature, the long line of traditional literary criticism is almost entirely non-existent: indeed almost without exception editions of Byzantine authors lack literary (and even grammatical) comment of any kind. To help fill this yawning chasm I wrote an article on Michael Psellos' imagery that is little more than a detailed catalogue of similes and metaphors in the Chronographia. ${ }^{2}$ The present work is a similar attempt for Niketas Choniates. ${ }^{3}$

In their influential literary study ${ }^{4}$ Alexander Kazhdan and Simon Franklin devoted the last chapter (256-286) to aspects of especially Choniates and Nikephoros Gregoras. Their most valuable comments, I believe, consider effective use of colour to communicate judgements, but a few pages (263-269) treat of imagery. Nonetheless, despite, for instance, the statement that "Choniates makes figurative use of a large menagerie of wild animals", we find in this category that, through constraint of space, they merely name nine mammals and three reptiles, with a small selection of references, and summarize two similes concerning them. They thus fail to indicate both the huge variety of images used and the historian's typically Byzantine obsession for variety of wording for the same image. It is my primary purpose now to illustrate these two types of variety, for the second of which the relevant passages are quoted nearly always in full in Greek (as well as

1 For a brief summary of approaches see A. R. Littlewood, Literature, in: J. Harris (ed.), Palgrave Advances in Byzantine History, London 2005, 133-146.

2 Imagery in the Chronographia of Michael Psellos, in: C. Barber/D. Jenkins (eds.), Reading Michael Psellos (The Medieval Mediterranean 61), Leiden/Boston 2006, 13-56. I have not yet seen the contemporaneously published article by E. McCartney, The Use of Metaphor in Michael Psellos' Chronographia, in: J. Burke (ed.), Byzantine Narrative: Papers in honour of Roger Scott (Byzantina Australiensia 16), Melbourne 2006, 84-91.

3 As with Psellos there seems to be no important distinction between metaphors and the far more

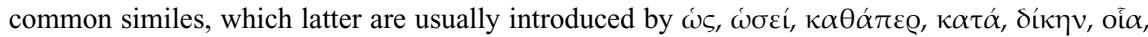

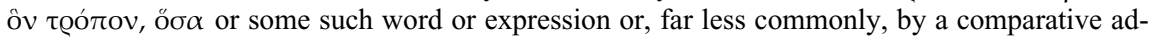
jective or adverb or a verb of comparison.

4 Studies on Byzantine Literature of the Eleventh and Twelfth Centuries, Cambridge 1984. 
in translation), ${ }^{5}$ thus also giving some idea of Choniates' vast vocabulary. Since I too, however, suffer from constraint of space, I have chosen to treat of only two areas of imagery - vegetal and animal. This is unfortunate since some of his most memorable images involve quotidian actions or objects. ${ }^{6}$

Vegetal imagery has a long lineage in Greek literature from the time of the Homeric poems, where stalwart warriors were compared to vigorous trees in the Iliad and where the erotic element is introduced in the Odyssey (6.163) in a comparison of Nausikaa with a palm.

Thus in Choniates the youthful Conrad, son of William of Montferrat, is, in a

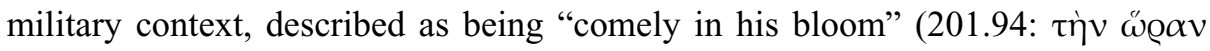
$\varepsilon \dot{v} \pi \rho \varepsilon \pi \tilde{\eta})$, while a statue of the warrior maiden Athene has a body that "though

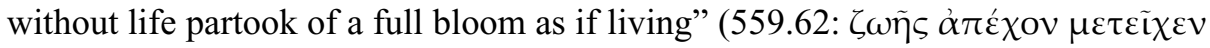
$\omega \varsigma \zeta \tilde{\omega} v \dot{\alpha} v \theta \eta \emptyset o ́ \tau \eta \tau o \varsigma)$. The emphasis is, however, always more on beauteous or vigorous (or both) youth, rather than on stalwart prowess. Thus, perhaps inspired by Iliad 18.56 and Odyssey 6.163, Choniates has Alexios II Komnenos as a child

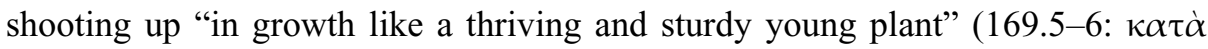

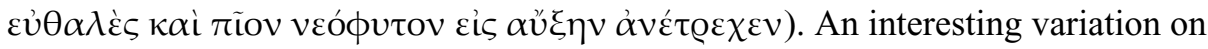
this theme is the example of Constantine Doukas who, as a youth with his first beard, "promised, like plants of good stock, to bear fruit prematurely" (193.63-

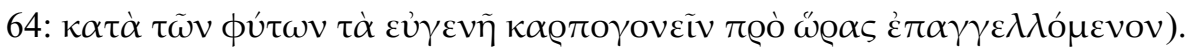

Simply to describe the beauty on which he depended as his matchmaker

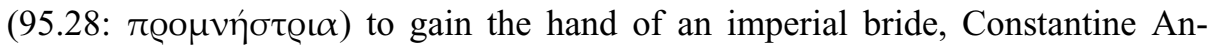
gelos is said to have been "cultivating a meadow of beauty on his face" (95.26:

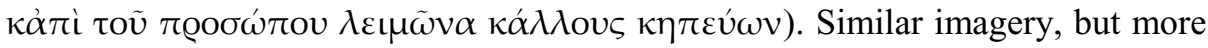
extended, makes Manuel I Komnenos compare the young Istvan succeeding his father Geza II on the Hungarian throne as "some most beautiful growth from a

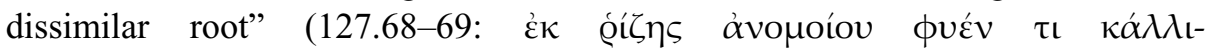
$\sigma \tau \mathrm{\tau})$. Choniates gets even farther from Homeric imagery with the youthful Andronikos I Komnenos who is like a "climbing shoot of fir" (139.50: ع̌pvos

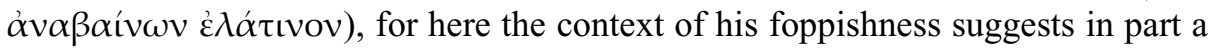
bad sense, something brought out more fully in "the flower of youth" (54.69: tò

5 All quotations are from the text of I. A. van Dieten, Nicetae Choniatae Historia (CFHB XI/I Series Berolinensis), Berlin/New York 1975 (I have retained van Dieten's punctuation even when I find it illogical). All translations, deliberately literal rather than literary, are my own (I have modernized names of peoples, e.g. Byzantines for P $\omega \mu \alpha \tilde{i}$ ) $)$.

6 One of the most memorable involves Constantine Mesopotamites' policy in the reign of Alexios III Angelos: he held the church in his left hand, the palace in his right "tying [them] closely to-

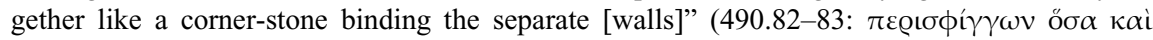

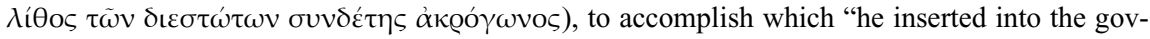
ernment his own brothers like wedges or hoops, or he hung them like earrings in both the em-

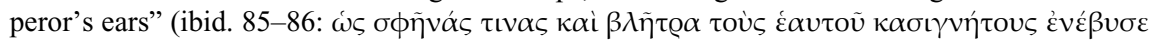

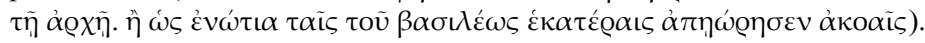




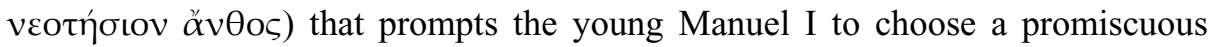
way of life. On the other hand the imagery may still be of vigorous manhood, but with an ominous twist: Manuel observed that pacifists forget that "thereby more

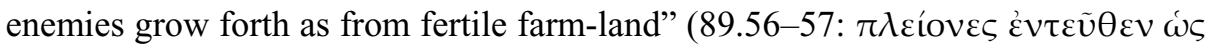

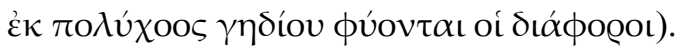

Application of vegetal imagery to a female occurs first in Greek literature with Homer's Nausikaa, and thereafter it becomes far commoner than the application to males. Choniates, however, despite his numerous references to marriages of beautiful ladies, largely eschews it. With the exception of the rather masculine Athene he has only two instances. The daughter of Manuel I is "tall like a damp 7

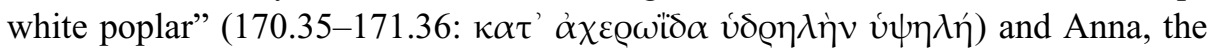
daughter of Alexios III Angelos, enjoyed a veritable "rose-bed of beauty"

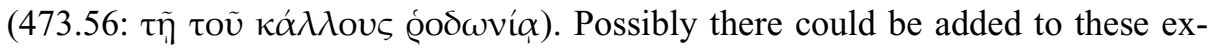
amples Choniates' report that Manuel for her prudence called his niece, the wife

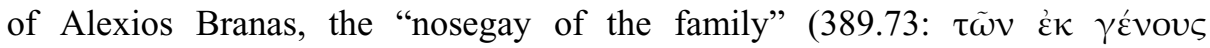

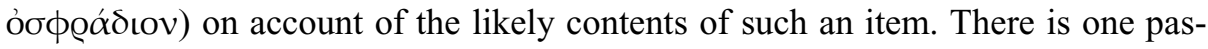
sage that applies the imagery to both male and female: when Andronikos married Anna "the ripe had no shame to lie with and embrace the unripe grape, the overripe the lass with upstanding breasts, the shrivelled and languid the rosy-fingered

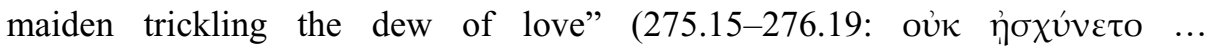

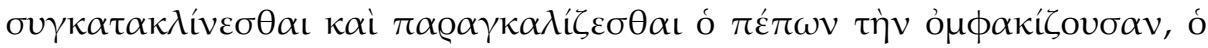

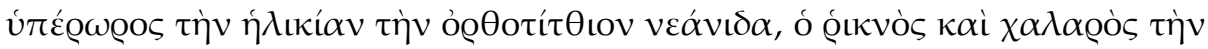

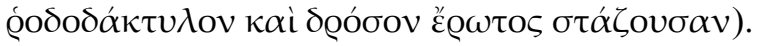

Comparison of a part of the human body with vegetation is a regular theme of Greek literature (as of other literatures and, most influentially for the Byzantines in especially Marian imagery, of the Old Testament's Song of Solomon). It has little interest for Choniates, perhaps because he associates it with popular, and especially erotic, poetry. Nonetheless we find the commonplace imagery of lips, in this case those of Athene's statue (652.69-70), as flower-buds (кó $\lambda v \kappa \varepsilon \varsigma$ ), while monks "grow their field of beard long like a deep crop of corn" (558.32:

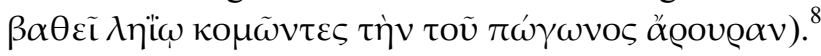

Far away from the imagery of youthful vigour and beauty we find the Byzantine army during an anxious night in camp "turning pale through fear just as the leaves of trees change (in colour) during the leaf-shedding season" (187.90-92:

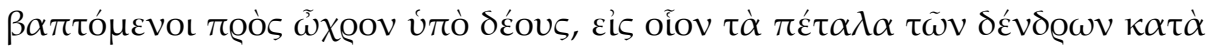

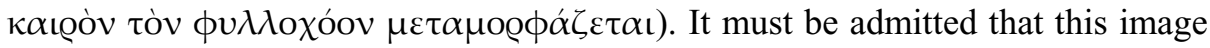
is not very effective and its author must have been thinking simply of change of

7 From a refreshing spring shower or from dew or being full of sap?

8 For a beardless face compared to a field stripped of corn see below, 229. 
colour rather than the specific hues, ${ }^{9}$ for the vernal rather than the autumnal are closer to the pallor of fear in men's faces. Far better is the brutal comparison of the mutilated Andronikos, lacking a hand and an eye, with a "leafless old stump"

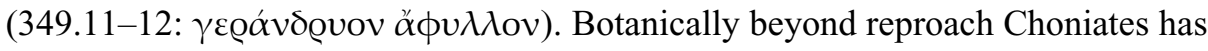
Alexios III "clinging" to Constantine Mesopotamites, who in another passage is to the emperor as "all the herbage of the field", 10 "as firmly as ivy" (490.64-65:

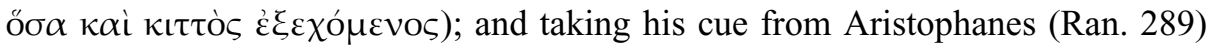
he makes Alexios III "thunder back with fury like a holm-oak suddenly bursting

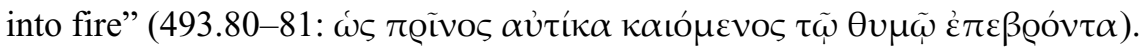

Common imagery appears in his metaphor of the traitor John Spyridonakis as

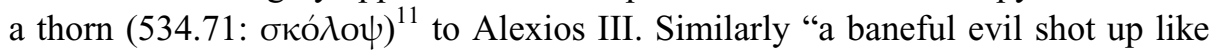

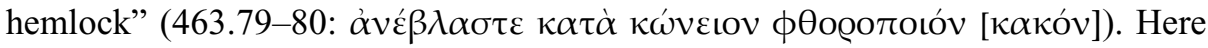
the evil is the person of Isaac Doukas, but elsewhere one generation of men "engendered hemlock that ripened for no other reason than death" (292.56-57:

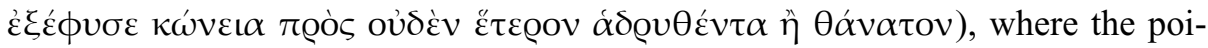
sonous plant is the following generation. More elaborate is the porphyrogenita Maria's insistence that the protosebastos Alexios "be cast utterly out of the palace with curses, be torn away like some tare that had grown alongside the noble planting and be punished with ruin for climbing and choking the emperor as if he

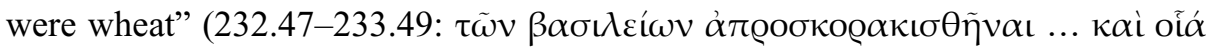

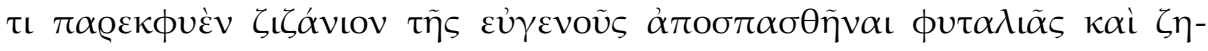

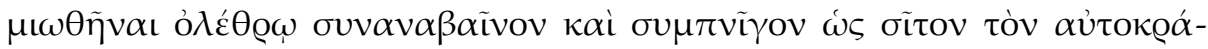
$\tau \mathrm{\tau O} \alpha)$.

Homer (Il. 23.597-599) is his model when Choniates says that Andronikos'

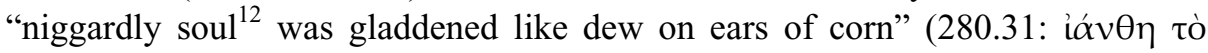

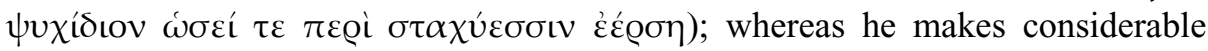
changes with another vegetal Homeric simile in claiming that Manuel I "sprouted forth in new vigour like the prolific crop of a rich man that demands reapers in the

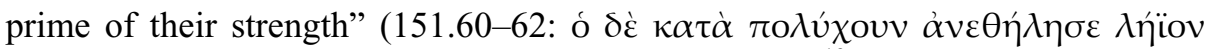

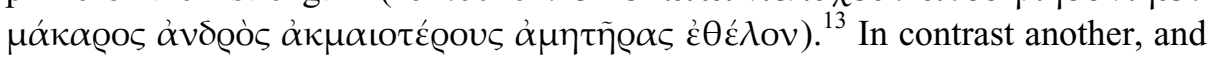
remarkable, image appears to be at least largely his own: "the mighty of the earth

9 Homer (Il. 3.35) uses the noun $\tilde{\omega} \chi \varrho \circ \varsigma$ in a context of fear, but without any vegetal comparison.

10 484.92-485.93, quoting Job 5.25.

11 Although the word can mean simply "stake", "thorn" would fit Choniates' customary imagery better and his association of the word with Satan suggests that he had in mind II Ep. Cor. 12.7, where the addition of the words $\tau \tilde{\eta} \sigma \alpha \varrho \kappa i$ makes "stake" unlikely.

12 H. J. Magoulias' translation (O city of Byzantium, Annals of Niketas Choniates, Detroit 1984) of Choniates' $\psi v x$ ísıv.

13 Homer has Greeks and Trojans sweeping like reapers through a rich man's fields of wheat or barley with thick handfuls falling (Il. 11.67-69) as they slay each other. Choniates keeps the military context because Manuel is invigorated by imminent war. 
are really like high-reaching and leafy-crowned pine-trees; for, as these rustle when the needles of their branches are violently shaken by short blasts of wind, so these men do indeed both look askance at the man abounding ${ }^{14}$ in wealth and cower before the man who is superior to the majority in manliness" (143.47-51:

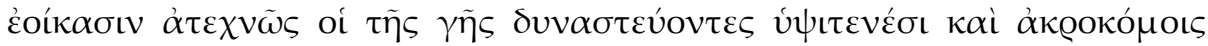

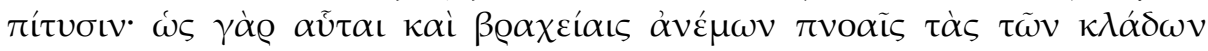

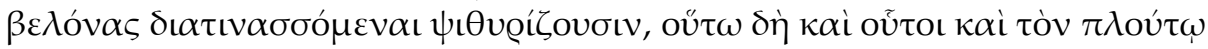

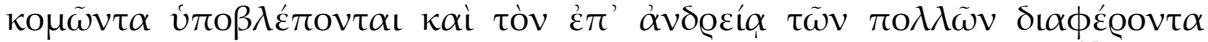
$\kappa \alpha \tau \varepsilon \pi \tau \eta \dot{\eta} \chi \alpha \sigma \iota)$. Another instance of vegetal imagery applied to humans ${ }^{15}$ occurs in Andronikos returning to former ways like a branch springing back after being

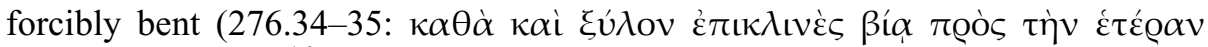
$\varepsilon \dot{\xi} \xi \nu \mu \varepsilon \tau \varepsilon v \varepsilon \chi \theta \varepsilon \dot{v})^{16}$

Inanimate things both concrete and abstract enjoy similar imagery. Two of the former are Biblical. In his lament for the sack of the capital in 1204 he compares the inhabitants' scanty rags with the fig-leaves of Gen. $3.7^{17}(592.33$ :

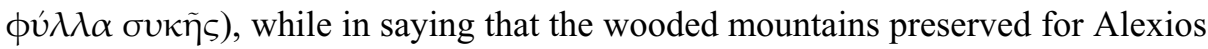

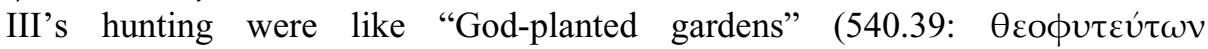
$\pi \alpha \varrho \alpha \delta \varepsilon i ́ \sigma \omega \nu)$ he probably had in mind Gen. 2.8. Further imagery in this category is non-Biblical. Thus Manuel had his military and other achievements depicted in his palaces in mosaics modelled "with flowers of variegated hue" (206.50-51:

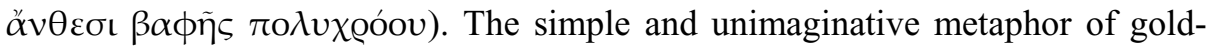
and jewel-encrusted robes imitating the flowers of a meadow is extended by Choniates in his description of the reception by Alexios III of German envoys at Christmas 1196: the Byzantines encouraged them "to gaze at the full bloom of the stones, with which the emperor was adorned like a meadow, and pluck vernal delights in the middle of winter" (477.79-81: $\dot{\varepsilon} \varsigma \tau \dot{\eta} v \tau \tilde{\omega} v \lambda \hat{\imath} \theta \omega \nu \alpha \ddot{\alpha} v \theta \eta v \dot{\alpha} \phi-$

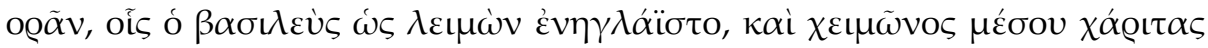
$\dot{\varepsilon} \alpha \varrho ı \dot{\alpha} \varsigma$ $\delta \varrho \varepsilon ́ \pi \varepsilon \sigma \theta \alpha \mathrm{l})$, but the Germans sternly bade them put off such finery for, if negotiations failed, the Byzantines would have to array themselves in battle against men "who are not blooming with stones like meadows with flowers"

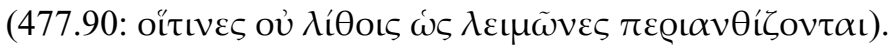

For abstract subjects Choniates again has recourse to the Bible. In criticizing Isaac II for believing that his rule was secure "like the stem of a palm growing afresh at the smell of water and that it would last lengthy cycles of years like a

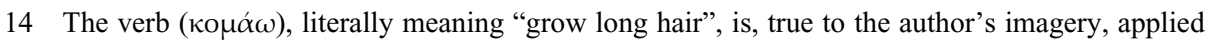
also, from the time of the Homeric Hymns (h. Cer. 454), to luxuriant vegetation.

15 For instances involving specific agricultural or horticultural practices see below, 227-231.

16 It may be noted also that Choniates uses part of the Homeric tag ("not from oak [or rock]": Od. $19.163)$ at $338.82-83$.

17 And the garments made from skins of Gen. 3.21. 


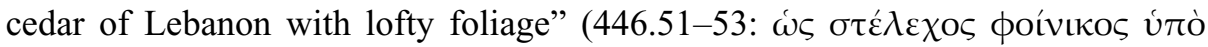

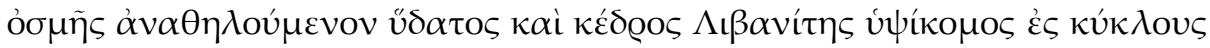

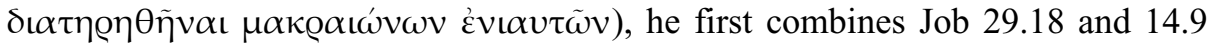
before adding from Ps. 91.13. In calling the military successes of Romanos, prince of Volynia and Galicia, kind deeds performed for the glory of Christian faith, he observes that the most minute part of the latter can, with adaptation of Saint Matthew's words (17.20), "remove and transport mountains like a mustard-

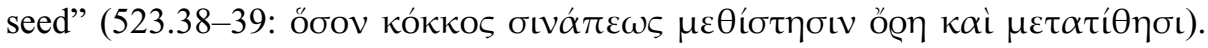
With inspiration from Job (21.18) money squandered by Alexios III "was dispersed like a heap of chaff and swiftly scattered in the summer's dust" (460.74-

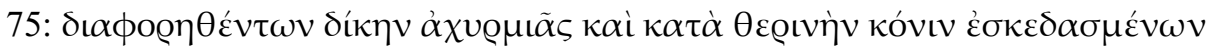
$\tau \alpha \chi \dot{\varepsilon}(\omega)$ ). In an interesting adaptation of Judg. 9.14-15 Choniates has some of the squabbling Latins after the conquest of 1204 choosing like birds "thorny brambles

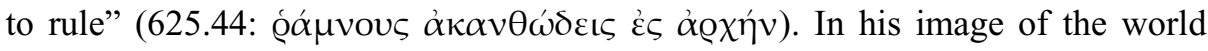
that would result from a reconciliation between East and West he adds to the Biblical beating of spears into ploughshares and companionable feeding of lambs with lions (Mich. 4.3; Is. 11.6, 65.25) "a lasting increase and unexpected growth of crops so that the thorn-bush would produce pears and the fig-tree bristle with

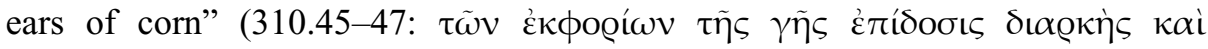

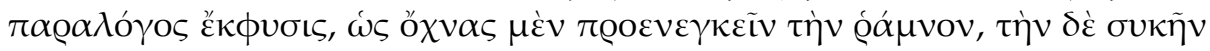

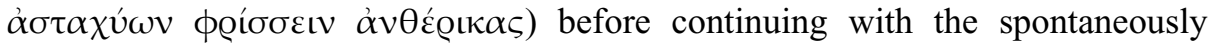
appearing lotus, crocus and hyacinth of Zeus' impromptu bed for love-making with his wife (Il. 14.348). ${ }^{18}$ There is probably no Biblical content in the use of "a

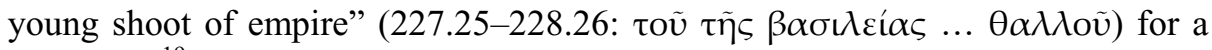
new reign. ${ }^{19}$

An imaginative simile is found for the tax-collectors who, after the contrivance of new taxes under Isaac II, "knead monies collected neither fitly nor legally with those collected justly like millet in a cultivated orchard ${ }^{20}$ or the poppy anem-

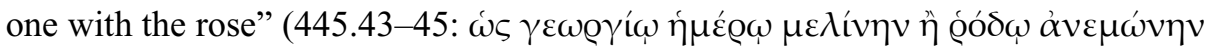

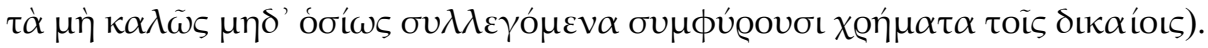
This may be compared with the second of a bizarre series of similes Choniates parades for the miracle of finding an act of kindness amid Andronikos' evil deeds, which "was like hunting for a highly prized panacea from the flesh of that serpent [viz. of Eden] and finding a preservatory antidote, and like plucking a fragrant

18 For quite different imagery consequent upon the meeting of East and West see below, 233.

19 It is just possible that Choniates was thinking of 2Macc. 14.4, but his (metaphorical) use of goats as the subject of the clause makes this unlikely. A certain further instance of Biblical imagery in this category is, however, the use of "sour grapes" from Ier. 38(31).29 and Ezek. 18.2 at $427.31-32$.

20 The word more commonly means "field", but "orchard" fits the context better. 
rose from thorns or at least setting before oneself a tasty banquet of starlings and

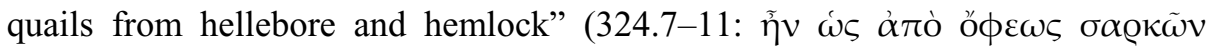

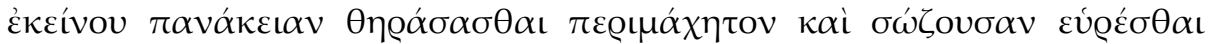

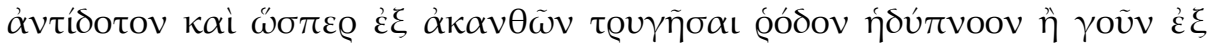

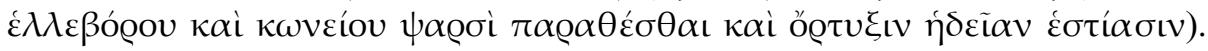
The metaphor of "the cutting down of the trees of the imperial garden" (269.94-

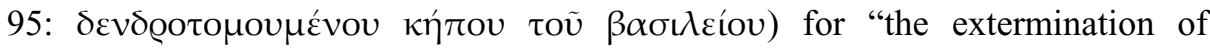
Manuel's family" is a nice reminder of the symbolism of power associated with an emperor's garden, ${ }^{21}$ although by the historian's time that has come to represent also the concept of renewal. ${ }^{22}$ Apart from a little unimportant, and perhaps even unconscious, imagery achieved by verbs, ${ }^{23}$ the only remaining passage in this category offers something quite different in describing Philippa's transference of affections from Constantine Kalamanos to Andronikos as her "Erotes fluttering their wings towards another, pelting Andronikos with apples and bearing torches"

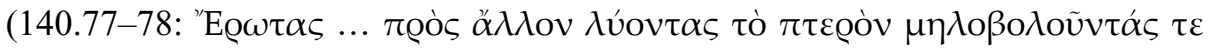

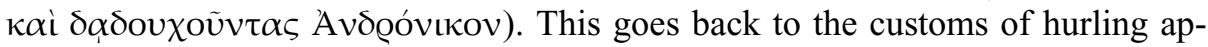
ples at a wedding-chariot to promote fertility (Stesichoros, fr. 10 Page) and of a girl thus advertising her affections (first found with Athenian prostitutes trying to attract clients in Aristophanes [Nub. 997]). ${ }^{24}$ Choniates will have been familiar with Erotes so playing from a bronze plaque of the fourth century A.D. which, though originally in a pagan temple in Dyrrhachium, had been built into the Averodoúdıov (between the Artopoleia and the Forum Tauri in Constantinople) and whose destruction by the Fourth Crusade he laments at 648.52-54. The game may even have been a joke in the family, for the historian's brother Michael uses

21 This has a long history. Actual destruction of royal trees had been carried out by invaders to assert their supremacy as early as c. 1458 B.C. in Egypt by Thutmose III and in the mid-ninth century B.C. in Assyria by Shalmaneser III (J. B. Pritchard, Ancient Near Eastern Texts Relating to the Old Testament, Princeton, N. J. ${ }^{3} 1969,240$, 280). For the tradition of the symbolism from the Near East to the Byzantine period see A. R. Littlewood, Gardens of the Palaces, in: H. Maguire (ed.), Byzantine Court Culture from 829 to 1204, Washington, D.C. 1997, 13-38 (esp. 18-21).

22 See H. Maguire, Imperial Gardens and the Rhetoric of Renewal, in: P. Magdalino (ed.), New Constantines: the Rhythm of Imperial Renewal in Byzantium, 4th-13th Centuries, Aldershot 1994, 181-197. For a further instance of an abstract see the "young shoot" ( $\theta \alpha \lambda \lambda$ ó $\varsigma$ ) of empire, below, 240.

23 Evils are "shooting up alongside" (447.94: $\pi \alpha \varrho \alpha \beta \lambda \alpha \sigma \tau \alpha v o u ́ \sigma \alpha \varsigma)$ virtues, which Choniates

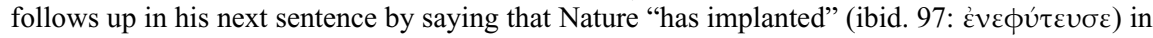

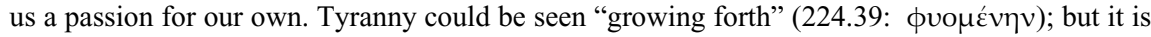
hard to decide whether $\kappa \alpha \varrho \pi i \zeta o \mu \alpha \iota$ and $\kappa \alpha \varrho \pi о \tilde{\mu} \mu \alpha \iota$ are used literally or figuratively at 142.28 and 613.62 respectively in the sense of "enjoying fruits of".

24 See A. R. Littlewood, The Symbolism of the Apple in Greek and Roman Literature, in: HSCP 72 (1968) 147-181 (esp. 154-155); id., The Symbolism of the Apple in Byzantine Literature, in: JÖB 23 (1974) 33-59 (esp. 38-39); id., The Erotic Symbolism of the Apple in Late Byzantine and Meta-Byzantine Literature, in: BMGS 17 (1993) 83-103. 
the same extremely rare verb to describe his own exchange of affectionate letters with a friend. ${ }^{25}$

Although similes taken from agriculture begin in Greek with Hesiod, ${ }^{26}$ that and the allied science of horticulture did not become truly respectable for gentlemen, and consequently literary writers, until the Roman period. The Byzantines, being heirs of both the Roman tradition and the Biblical, elevated both sciences even further. ${ }^{27}$ It is, therefore, not surprising to find such imagery in Choniates. Many are naturally taken from the growing of man's basic food, cereals.

The preparatory ploughing furnishes but a single instance: the River Melas is small in summer when it passes "through earth ... cut to a deep furrow by plough-

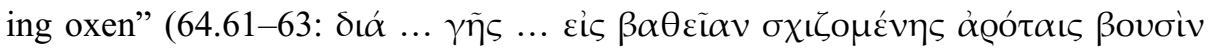
$\alpha u ̛ \lambda \alpha \kappa \alpha)$. Despite his fondness for the imagery of water, Choniates makes no imaginative use of irrigation ${ }^{28}$ except perhaps when in his preamble he claims that he is continuing the work of earlier historians and that his work is "interwoven [with theirs] to resemble in a fashion a channel of water issuing from a single

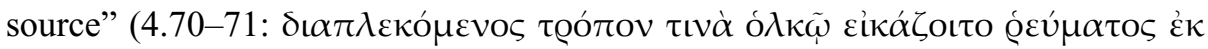

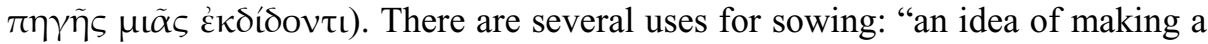
personal attempt at autocracy was sown in him [the rebel Ivanko]" (510.41-42:

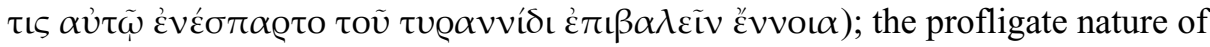
sowing is used to make it stand for squandering in Michael Palaiologos "lavishly

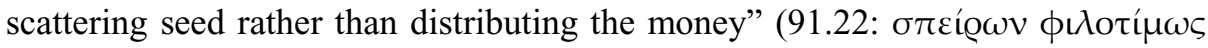

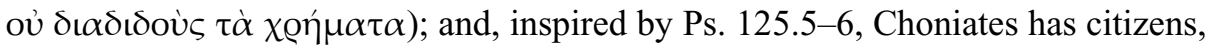
himself included, after the capital's sack in 1204 "casting lamentations like seeds"

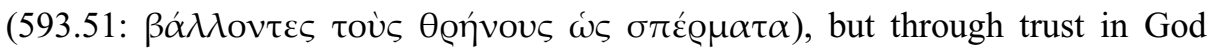
looking forward to "taking up with joy the sheaves of a more fortunate change"

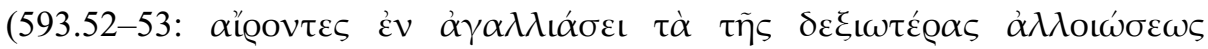
$\delta \varrho \alpha ́ \gamma \mu \alpha \tau \alpha)$. The same combination of operations is found twice more. Alexios V Doukas Mourtzouphlos, finding the treasury empty, nonetheless spent money in the very words of Matt. 25.26, "reaping where he had not sown and gathering

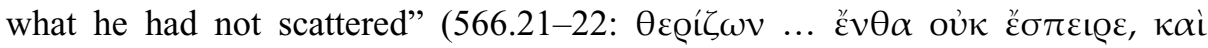

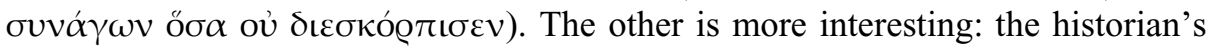
comment on the blame for John of Poutze's policy in persuading Manuel I to cut down expenses on the navy with the resultant growth of piracy is "even if we know the ear of corn of the sower, yet we blame also the reaper" (55.21-22: $\varepsilon \grave{\imath} \delta \dot{\varepsilon}$

25 Nicetae Choniatae orationes et epistulae, recensuit I. A. van Dieten (CFHB III - Series Berolinensis), Berlin/New York 1972, ep. 13.4.

26 Fr. 286 Merkelbach/West.

27 See Littlewood, Gardens of the Palaces (see n. 21), 16-18.

28 His watery images are mainly drawn from flooding rivers and the sea. 


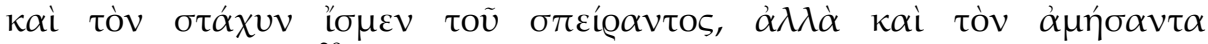
$\pi \varrho 0 \sigma \varepsilon \pi \alpha \iota \tau \iota \omega ́ \mu \varepsilon \theta \alpha)^{29}$

Reaping alone occurs on a number of occasions. Thus, to illustrate that during the reign of Andronikos civic strife was more deleterious to Asiatic cities than foreign invasion, Choniates writes "what a foreign-speaking hand did not reach,

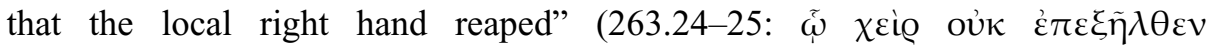

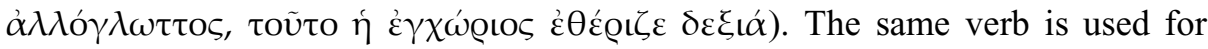
Andronikos' cutting down of high-minded and ingenious generals (143.46) directly after $\dot{\alpha} \kappa \varrho о \tau о \mu \varepsilon \dot{\varepsilon} \omega$ ("cut off ear of corn") is metaphorically employed to rid him of aristocrats. Even simpler is his description of Turks cut to pieces in battle

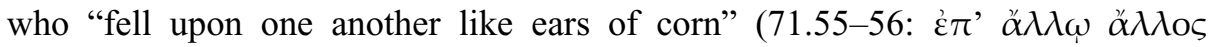

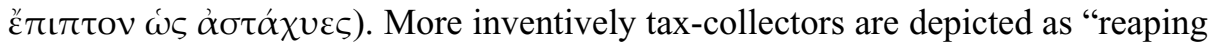
and binding the coins like sheaves and taking them together to the threshing-

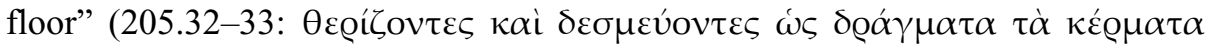

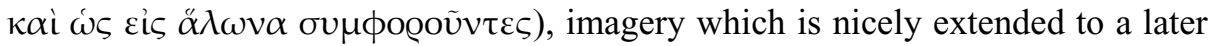
process with each man, having delivered a little to the emperor, "kneading loaves from the threshed wheat, that is the gold coins, for himself" (205.37-38: $\dot{\varepsilon} \alpha v \tau \tilde{\omega}$

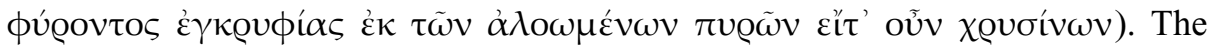
beard of the Latin patriarch Thomas Morosini was shaved "more closely than with pitch-plaster [a depilatory] so that the surface of his cheeks gave no indication at all of the initial growth of hair but was like a field completely plundered of

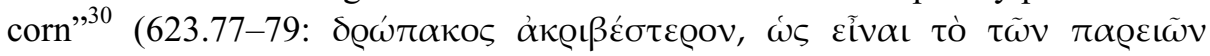

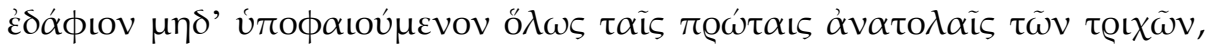
$\dot{\alpha} \lambda \lambda^{\prime} \omega \varsigma \Lambda$ ¡ only reaped but also gleaned, an image, through the simple use of the verb $\kappa \alpha \lambda \alpha \mu \alpha \dot{\alpha} \mu \alpha \iota$ (literally "gather corn-stalks"), used to describe the despoiling of the citizens of Thebes (74.45). Choniates employs this verb with $\dot{\varepsilon} \pi \mathbf{\phi} \phi \lambda \lambda i \zeta \omega$ ("glean grapes") to describe excessive taxation (537.56) and puts them into the mouth of a man boldly criticizing Manuel for his treatment of his subjects (186.63), while their cognate abstract nouns appear (636.64-65) in a passage rejected by van Dieten which describes the respite of cities governed during her regency by the Hungarian Margaret-Maria. The Herodotean tale (5.92) of Thrasyboulos' infamous advice to Periander of Corinth is not strictly an agricultural operation, but yet pertains to this imagery. Choniates employs it in unusual fash-

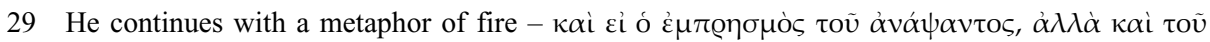

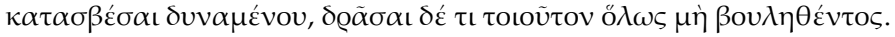

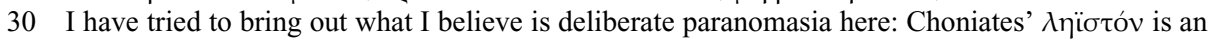
adjective signifying "to be carried off as booty", whereas the unrelated noun $\lambda$ íiov is a "standing crop" or "corn-field". A noun, or neuter adjective standing as a noun, is needed grammati-

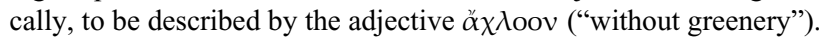


ion: "if it be a big and difficult thing for kings not to cut out the tallest ears of corn ... one would see that Alexios [III] was rich in this quality too" (548.3-5: $\varepsilon \dot{i}$

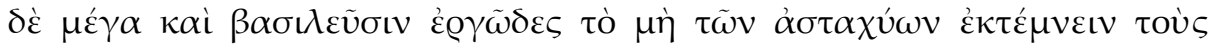

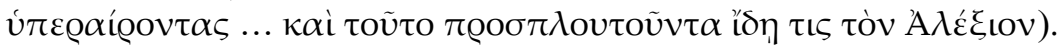

It is hardly surprising that in so military an history as that of Choniates more images of cutting are used than merely that of harvesting corn. Haymaking is only to be expected. A huge German "smote [his opponent's] horse across the legs and cut off both front ones with greater ease than a man could the grass of a field"

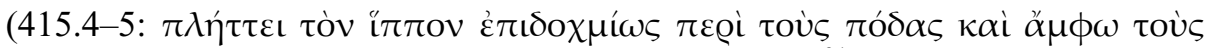

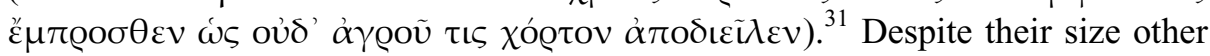
Germans, when the river Melas overflowed, "fell like grass and were swept away like sun-warmed rubbish of the farmyard or a light tuft of wool" (65.80-81:

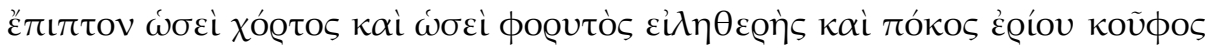
$\pi \alpha \varrho \varepsilon \sigma u ́(0 \nu \tau o)$. In the town of Athyras "children at the breast ... were harvested

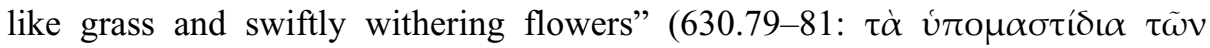

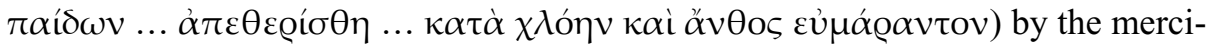
less Cumans. Destruction of sturdier plants also inspired the historian. He has Hungarians, opposed to Manuel's choice of the future Bela III as his son-in-law, "uprooting and cutting down the first shoots of his hopes" (128.6-7: $\tau \dot{\alpha} \varsigma \pi \rho \omega \tau \alpha \varsigma$

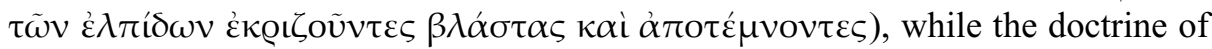
the heresiarch Sikidites that the body of Christ in the Eucharist was incorruptible the patriarch John Kamateros deemed necessary "to cut out root and branch"

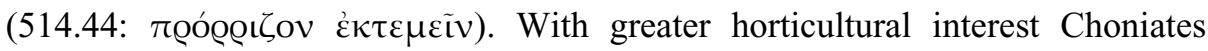
claims that Manuel, to stave off imminent rebellions, "counteracted the beginning of troubles by imitating the best gardeners who pull up young brambles, which damage the beds, and destroy the newly sprouted trees, which do not belong in a

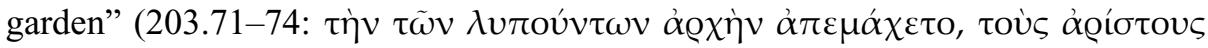

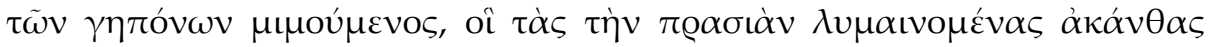

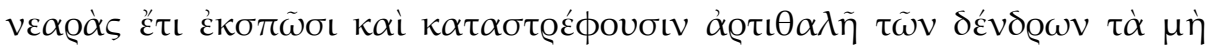
$\kappa \eta \pi \varepsilon v ́ \sigma \iota \mu \alpha)$. Pruning too is brought into service: Alexios III's virtues extended to him not chopping off opponents' fingers and toes, which is expressed in the words "he did not prune bodily extremities like vines" (548.6-7: oủ $\delta \dot{\varepsilon} \kappa \lambda \alpha \delta \tilde{\omega} v$

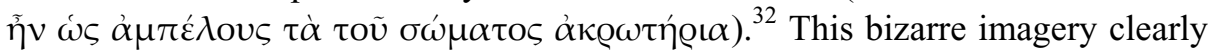
appealed to Choniates, for he had already used it with even more grotesque additions to describe the actions of Andronikos at Prousa: "he hanged many others on the branches of trees ... cut off the hands of some, pruned the fingers of others like vine-shoots and removed the feet of some more ... [and] returned to the pal-

31 The last part of the imagery is from Jer. 12.4, but there the grasses wither rather than being cut down.

32 The simile follows the reference to the cutting of the tallest ears of corn (above, 231). 
ace exulting in such trophies that he had gained [and] leaving behind the Prousaians' cultivated vines, which ran up and closely entwined the trees, weighed down with the corpses of those hanged like more clusters of grapes, and not allowing any of those impaled to be put into mounds for coffins, but these the sun baked and let be whirled around by the winds like apparitions [i.e. scarecrows] hung up in cucumber-beds by those who watch over fruit" (289.71-72,

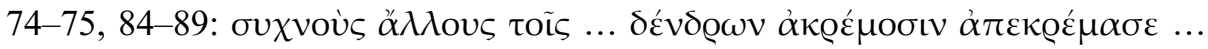

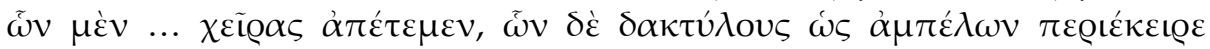

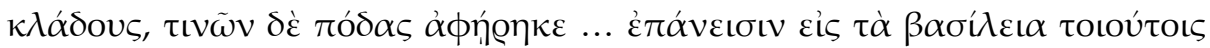

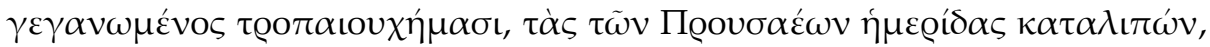

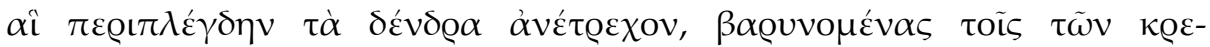

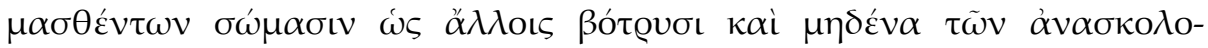

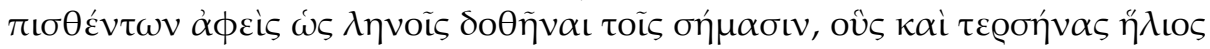

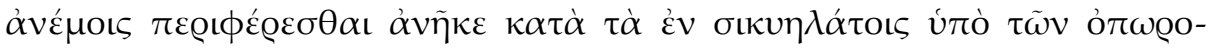

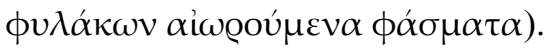

For grafting Choniates depends upon the famous Biblical passage at Rom. 12.24; yet he uses it in two completely different contexts. In the first he has courtiers disapprove of Manuel's plan to marry his daughter Maria to a Hungarian with the metaphor of "grafting the branch from an alien orchard onto a very fruit-

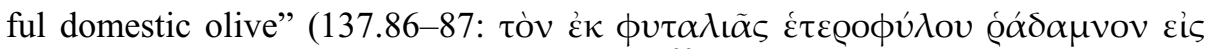

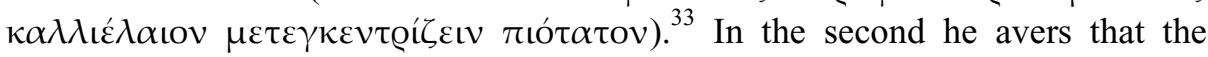
Byzantines should not deem the atrocities consequent upon the sack of 1204 "a grafting of barbarian wild olives onto our domestic olive" (581.29-30: $\tau \tilde{\omega} v$

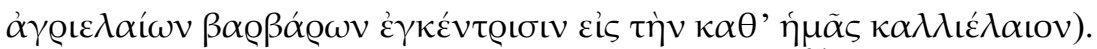

The last agricultural operation used by Choniates ${ }^{34}$ is the process of turning grapes into wine. While his Turks "fell like ears of corn", 35 they also "had their life-blood squeezed out of them as if they were bunches of grapes being trodden

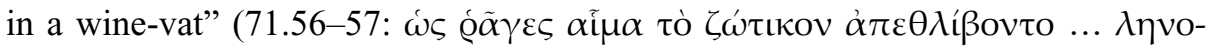
$\beta \alpha \tau o u ́ \mu \varepsilon v o$ ); but, in complete contrast, the venturesome and vigorous Theodore Kantakuzenos was like "fermenting wine newly trodden in the vat" (284.29:

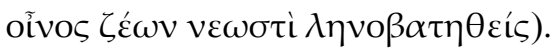

Whereas both Psellos and Choniates show great, and typically Byzantine, interest in vegetation for imagery, there is a huge disparity in their enthusiasm for the animal world. Psellos specifies only the lion, the monkey, snakes and the

33 Psellos had already used the passage for an imperial marriage of which he approved (Chron. 6.15.10-13).

34 Unless one can count the again Biblical imagery (Ps. 7.16, Prov. 26.27, though Choniates uses different vocabulary) when the Turks "slipped into the pit that they had dug with their own

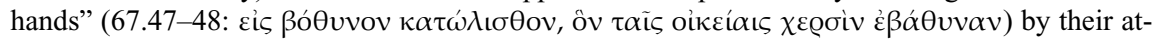
tack on the Franks (I ignore the exact quotation from Jer. 12.1-2 at 291.53-55).

35 Above, 231. 
mythological griffin; ${ }^{36}$ Choniates names no fewer than sixty-eight species comprising twenty-two mammals, twenty-one birds, twelve insects, six reptiles, two molluscs, two fish, one amphibian, one arachnid and the mythical composite Chimaira.

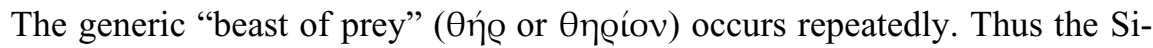
cilians in Thessaloniki in 1185 are "fiercer than beasts" (304.88: $\alpha \gamma \varrho t \omega \tau$ ć

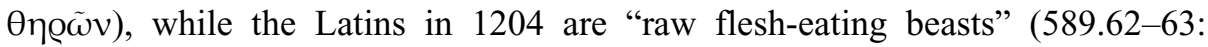
$\omega \mu \eta \sigma \tau \dot{\alpha} \varsigma$... $\theta \tilde{\eta} \varrho \alpha \varsigma)$; Manuel informed his troops that the Byzantines should have driven out the Turks "like wild beasts from flocks" (70.29: $\omega \varsigma \theta \tilde{\eta} \varrho \alpha \varsigma$ غे $\pi o u \nu v i \omega v)$; Isaac rescued captives "as out of the mouth of wild beasts" (398.15-

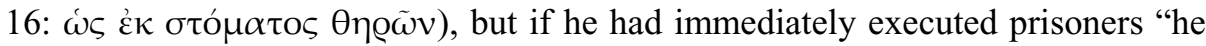
would have quite irrationally changed his nature for that of beasts" (364.31-32:

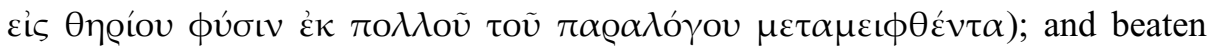
Venetians are likely to be "jumping up and leaping forth like wild beasts that are

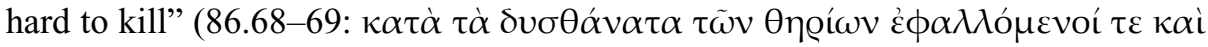
$\left.\pi \varrho 0 \sigma \alpha \lambda \lambda{ }^{\prime} \mu \varepsilon v o r\right)$, a theme that Choniates varies with "for who has pursued a bloodthirsty beast without seeing it shortly after leaping up and seizing [its

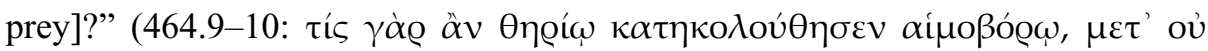

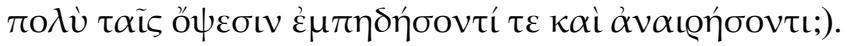

Choniates calls his bête noire Andronikos a beast no few than seven times, but with sufficient literary artistry to make each instance different. Infatuated by

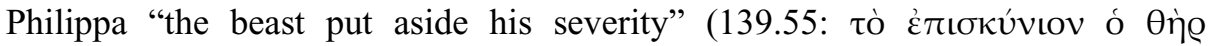
$\dot{\alpha} \pi \varepsilon \beta \dot{\alpha} \lambda \varepsilon \tau \mathrm{c})$; when he entered the palace for his coronation "the beast, changing

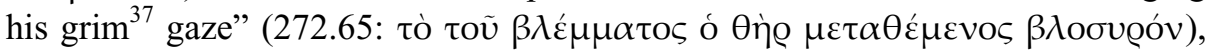
made promises of a change for the better; even without his imperial regalia the inhabitants of Chele "feared the beast even though he was naked" (348.65-66:

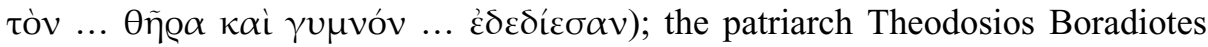
was "unwilling to enrage the beast and have him roaring against him" (254.15:

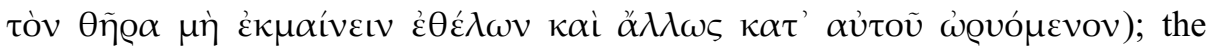
rebel Andronikos Lapardas, although he "thought to escape destruction and not be served up as a prepared feast and ready dessert for the jaws of Andronikos", ...

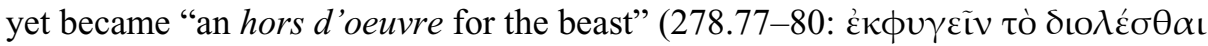

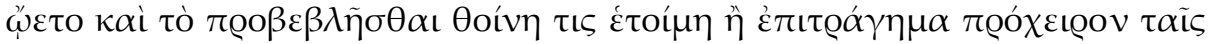

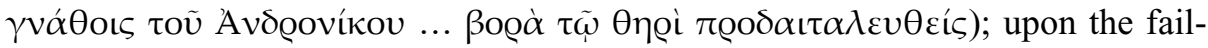

36 The lion is used seven times, the others once each (the monkey only for his pelt). He has recourse also to the non-descript $\theta$ ńe and indulges in lengthy imagery of a $\zeta \tilde{\omega}$ ov for the body politic (see Littlewood, Imagery [see n. 2], 22 and 35-38). Kazhdan and Franklin point out (Studies in Byzantine Literature [see n. 4], 268) Nikephoros Gregoras' similar lack of enthusiasm for specific animals.

37 The adjective, originally meaning "hairy" or "bristling", is used of lions by Hesiod (Sc. 175). 
ure of the emperor's trick of mounting Euphrosyne Kastamonitissa upon a siege engine as a human shield he was, when the Nikaians rescued her, left "to beat himself like another Phineus since he had nothing which he could place before the

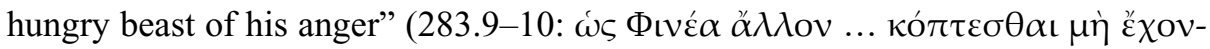

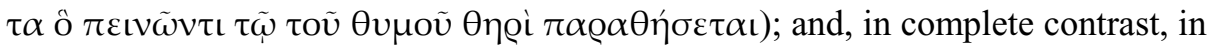
search of sexual dissipation he would leave the city with a group of courtesans and "carefully pick out quite deserted spots ... pushing his way, like wild beasts,

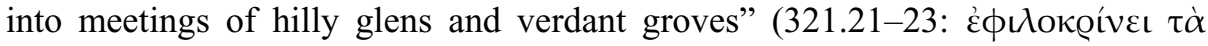

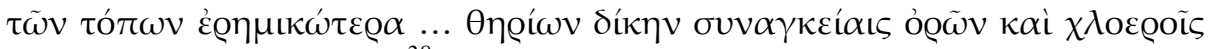

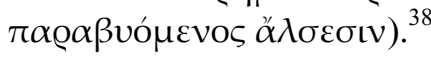

The hunger of beasts appears in two further instances: Stephanos Kontostephanos encouraged his troops to fight bravely against "barbarians with the

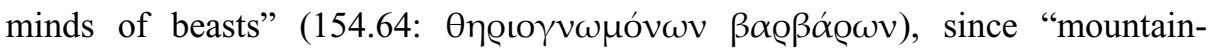

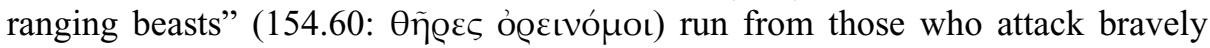
but men who fear to stand their ground "are set before them for an already pre-

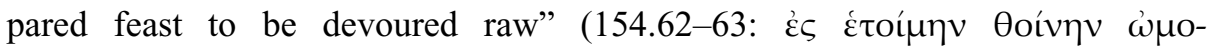

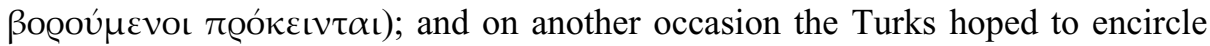
the Byzantines and "like wild beasts gulp down an as it were well prepared dish or carry off abandoned eggs and a deserted nest" (188.36-38: $\omega \sigma \pi \varepsilon Q ~ o ̋ \psi o v ~ \varepsilon \dot{v-~}$

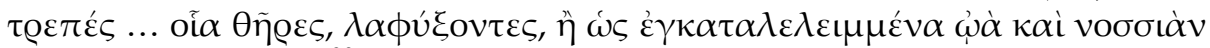

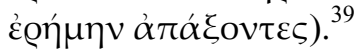

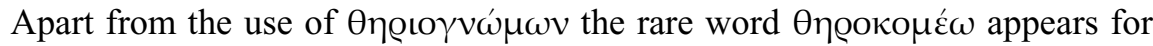
Euphrosyne's taming of her wild husband (489.41-42) and Manuel's failure to do the same to Kilij Arslan (123.76), although later the same emperor dealing with the same sultan, "as though goading a slumbering flesh-eating beast, enraged him and roused him from his lair (175.31-32: ő $\sigma \alpha \kappa \alpha i$ Ө

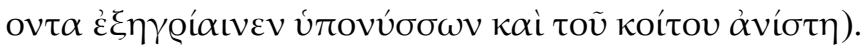

The more neutral word $\zeta \tilde{\omega}$ ov ("animal") is used figuratively twice, the first time quite briefly: Andronikos "deployed his army" against Thoros "as if it were an animal into head, rear part and limbs proportionate to the whole" (138.9-10:

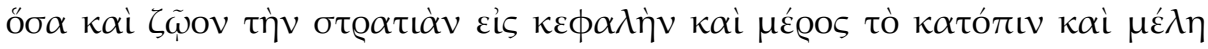

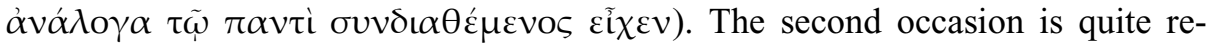
markable as Choniates compares the Byzantines' anguish for their captured city with that of animals longing for a captured companion put on display: "in addition we simply suffer as do some animals for those of their number trapped by hunters and enclosed in transparent glass cages; and, although by means of the clarity and brightness of the vessel they see as through a mirror the sight of their

38 For the continuation of this imagery see below, 238.

39 The second half of this imagery is taken from Is. 10.14 . 
fellow animal, they are yet wholly unable to join it or come into bodily contact with it, and consequently in distress they move round the vessel stupefied by the alteration in its appearance which is so at variance with its former state" (579.59-

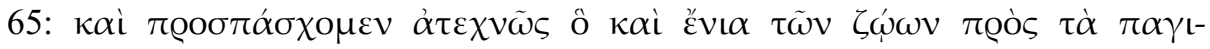

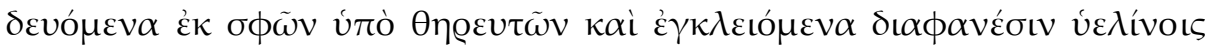

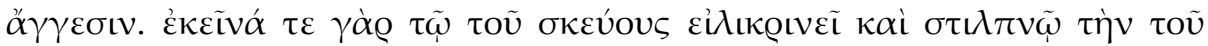

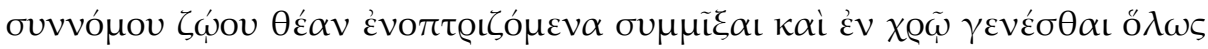

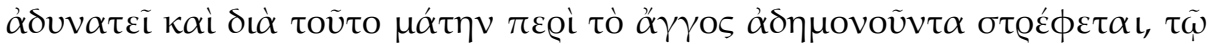

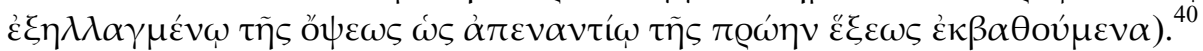

Choniates' favourite mammal is the lion, for which four of his comparisons come, with considerable verbal changes, from Homer. Thus wits proclaimed that Andronikos, rather than praying at the tomb of his cousin Manuel, was promising the deceased emperor that he would attack his family "like a lion having encoun-

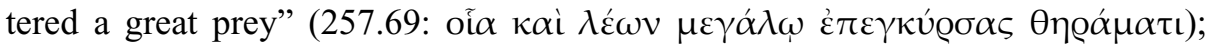
when Andronikos had taken Prousa, "like the ravenous king of beasts, falling upon animals without shelter and shepherds, he broke the neck of one, gorged himself on the entrails of another and in other wise treated a third extremely

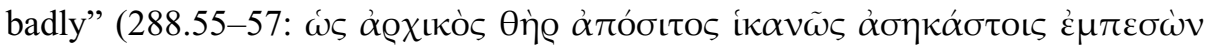

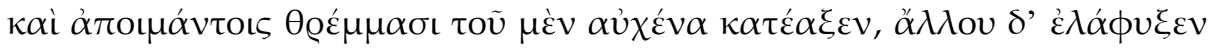

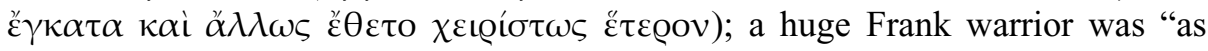

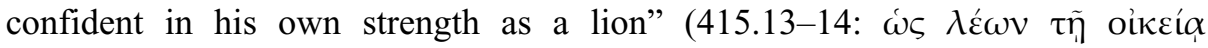
$\pi \varepsilon \pi \mathrm{ot} \theta \omega \varsigma \oint \omega \omega \eta \eta)$; and Manuel cut down the ranks of the barbarians "like a lion, trusting in its strength, herds of cattle or flocks of goats" (90.94: $\omega \varsigma \lambda \hat{\varepsilon} \omega \nu \dot{\alpha} \lambda \kappa \tilde{\eta}$

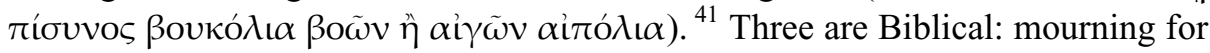
his wife Manuel "roared forth a lamentation like a lion" (115.48-49: $\omega \varsigma \lambda \varepsilon \dot{\varepsilon} \omega \nu$

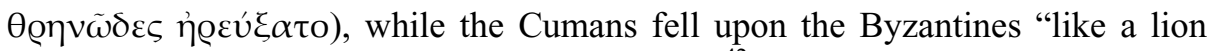
among cattle" (468.13: $\omega \varsigma \dot{\varepsilon} v \kappa \tau \eta \dot{v \varepsilon \sigma \iota ~} \lambda \dot{\text { ov }} \tau \alpha) .{ }^{42}$ In the third, to show Manuel's distrust for the Franks in 1146, Choniates has combined Matt. 7.15 with both Aesop (Fab. 199) and the paroemiographer Zenobios (1.93) - the emperor was

40 This is one of the rare passages in Choniates where the figurative imagery is then restated in terms of the subject to which it is applied, introduced here by "and we equally ... " (579.65-69:

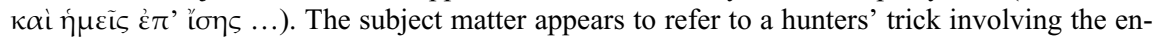
closing of a tiger-cub in a glass cage which is described (with remarkable similarities of emotional effect) in a tenth-century letter of Symeon Magistros and Logothete of the Dromos (J. Darrouzès [ed.], Épistoliers byzantins du Xe siècle, Paris 1960, ep. 89.23--32). I am grateful to Michael Grünbart for reminding me of this passage and drawing my attention to a discussion of it by Stratis Papaioannou (Der Glasort des Textes: Selbstheit und Ontotypologie im byzantinischen Briefschreiben [10. und 11. Jh.], in: W. Hörandner/J. Koder/M. A. Stassinopoulou (edd.), Wiener Byzantinistik und Neogräzistik [Byzantina Vindobonensia et Neograeca XXIV], Vienna 2004, 330-333.)

41 After Il. 3.23, 11.173-176, 5.299, Od. 6.130-132 respectively.

42 From Hos. 11.10, Mich. 5.7 respectively. 
suspicious "lest in some way they were coming as wolf cubs in the pelts of sheep or were lions disguised as asses, to reverse the fable, or were combining the lions'

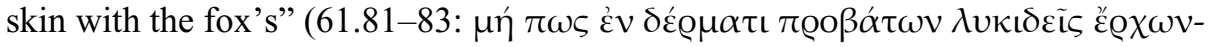

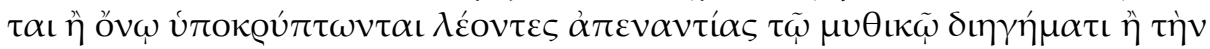
$\lambda \varepsilon \operatorname{cov} \tilde{\eta} v \xi \cup \vee \varepsilon ́ \chi \omega \sigma \iota \tau \tilde{\eta} \dot{\alpha} \lambda \omega \pi \varepsilon \kappa \tilde{\eta})$. The same proverb is used a second time for Andronikos' pretence towards the Nikaians when "having no lion's skin ... he

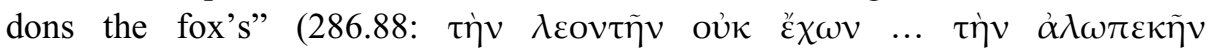

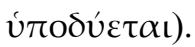

Choniates' other uses for the lion are more original, even though they still depend upon its ferocity and ravenous hunger. Three are quite brief and simple:

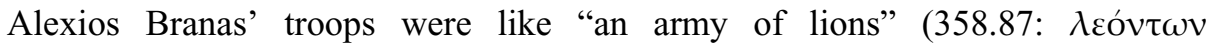

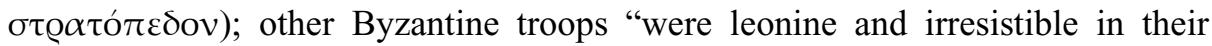

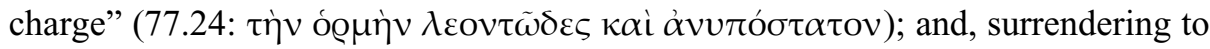
the opportunity of punning, Choniates compares Leon Monasteriotes, for his loud

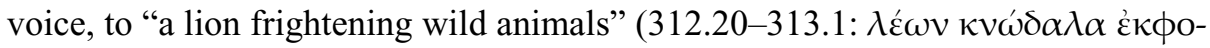
$\beta \tilde{\omega} v)$. Two similes concern avoidance of trouble. The first is the general comment "as soon as a hunter espies or hears a tawny snake or shaggy-maned lion in the mountains he immediately turns aside" (113.82-83:

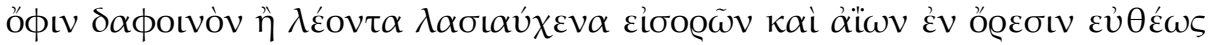
$\dot{\varepsilon} \xi \dot{\varepsilon} \kappa \lambda\lrcorner v \varepsilon v)$. The second is in reference to some members of the imperial family in 1203 who shun battle with the Latins "more readily than an army of deer [does]

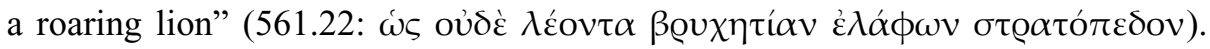
The zeal of the Frankish soldiery for the taking of live captives at Thessaloniki is explained by the not entirely satisfactory rhetorical question "what death-bringing viper or deadly heel-menacing snake or bull-slaying lion passing over yesterday's

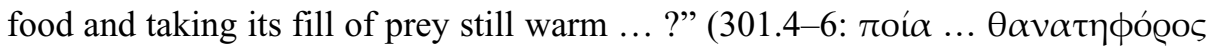

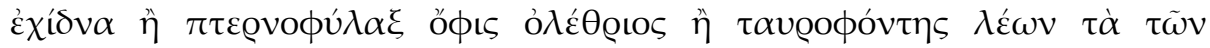

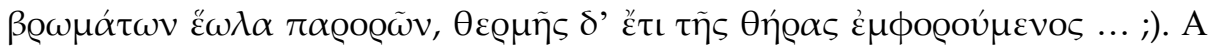
simile to indicate reversal of military fortune runs "leaping like a lion from a thicket, dealing destruction like wolf cubs and pouncing like a leopard, the captors became captives and the victorious were vanquished" (362.81-84: $\omega \varsigma$ غं $\kappa$

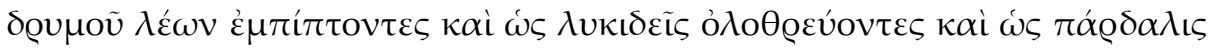

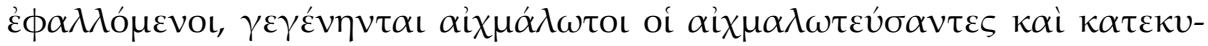

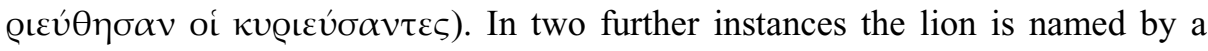
periphrasis: Conrad III is described as "the king of beasts, stung in the tail and rushing to leap forward although he has feasted less than a day before" (63.33-35:

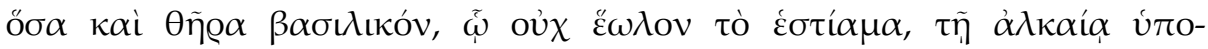

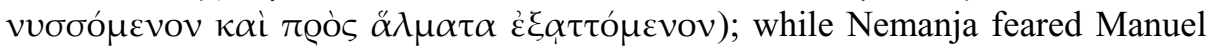

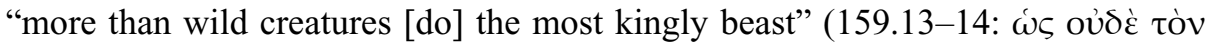
$\beta \alpha \sigma \iota \lambda \iota \kappa \omega \tau \alpha \tau$ เov $\theta \tilde{\eta} \varrho \alpha \tau \dot{\alpha} \kappa \nu \omega \dot{\delta} \alpha \lambda \alpha$ ). A further complimentary instance involves 
this animal - Constantine Angelos Doukas trained his troops to obey and fear him despite his youth "revealing his spirit like lion cubs immediately at birth [do] their proud expressions, the shagginess of their manes and the sharp points of their

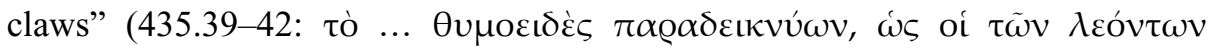

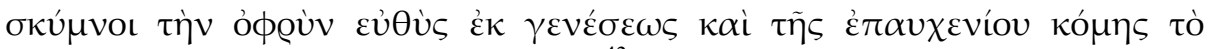

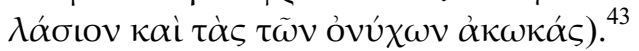

The other feline beast of prey mentioned, the leopard, appears once more, but only by means of a proverb to point the perjury of Desa. Rather inartistically Choniates makes the Serbian župan, who has just been compared with a chame-

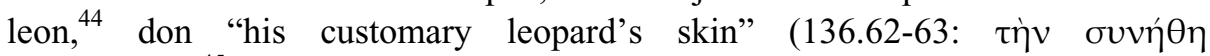
$\pi \alpha \varrho \delta \alpha \lambda \varepsilon ́ \eta v)^{45}$ to quote Euripides" infamous line "My tongue has sworn, but my mind is unsworn" (Hippol. 612).

The commonest Byzantine predator, the wolf, makes eight appearances. Only two do not mention sheep or shepherd, one (98.95) consisting of the single word $\lambda v \kappa о \phi \iota \lambda i ́ \alpha$ (wolf's, i.e. false, friendship) for a treaty. ${ }^{46}$ In the simplest of the others the historian saw, after the fall of the capital, a Latin seize a young girl "like a wolf a lamb" (590.66: $\omega \varsigma \alpha \dot{\alpha} \mu v \alpha ́ \delta \alpha$ úkos). Saint Matthew's famous image of "wolves in sheep's clothing" (7.15) is used twice (61.81-82; 248.73-74). Two further Biblical passages ${ }^{47}$ help to describe Eustathios, the good archbishop of Thessaloniki, as "having chosen to suffer evils with his own flock rather than imitate hired hands who flee, abandoning their animals, upon the arrival of the

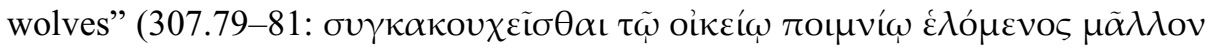

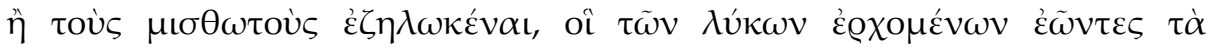

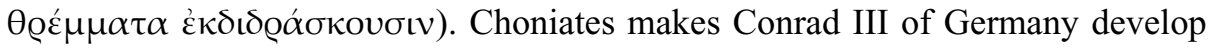
a hint from Theokritos (5.38) in claiming to his troops before the battle of Maeander in 1148 that the Byzantines "rear wolf-cubs [the Turks] for themselves as sacrificial beasts and fatten them ingloriously on their own blood, although they should ... drive them from their own lands and cities like beasts from their

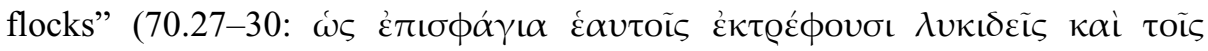

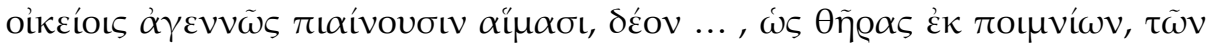

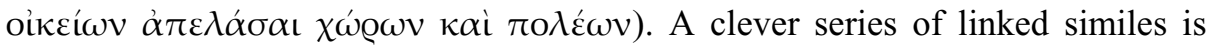
deployed when the citizens heard of the arrest of Kalomodios and persuaded John Kamateros to write a letter to the emperor as if it were a shepherd's pipe (524.76: $\sigma \tilde{v} \varrho(\gamma \xi)$ in order to summon back to them the money-changer "like a lost and

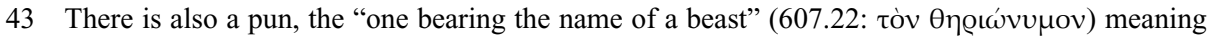
Leon Sgouros.

44 See below, 249.

45 Eustathios tells us (ad Il. 3.17, 374) that a leopard's may be substituted for the commoner fox's skin (cf. Macar. 8.17) to denote deceit.

46 The other is at 362.82 quoted above, 237.

47 Hebrews 11.25 and John 10.12 . 


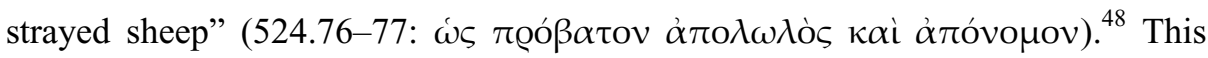
the patriarch managed successfully, restoring Kalamodios "like the sought-after lamb without him being fleeced of his gold by his wolfish gaolers" (524.79-81:

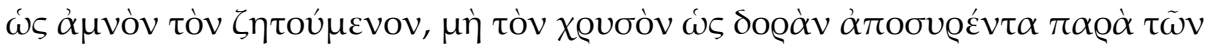

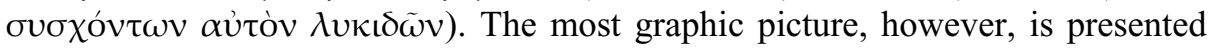
by Manuel refraining from demanding the surrender of Armenian fortresses from Thoros II since that would have been "tantamount to a shepherd trying to extract a

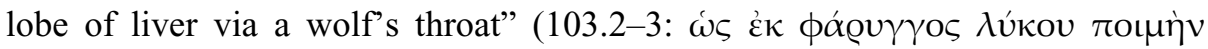

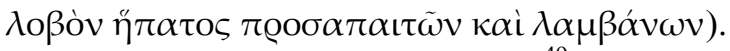

Predators' victims appear again. ${ }^{49}$ Uroš II "abandoned his own people to invaders to be scattered and killed like herds of domestic animals browsing on the

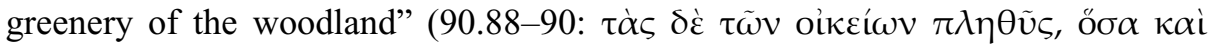

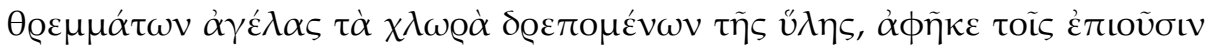

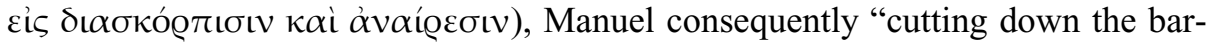

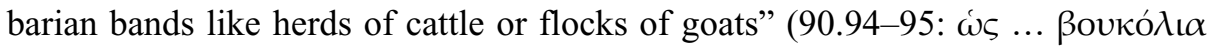

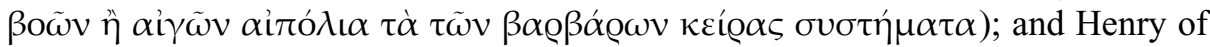
Flanders slaughtered the inhabitants of Apros "as if they were a flock of sheep or

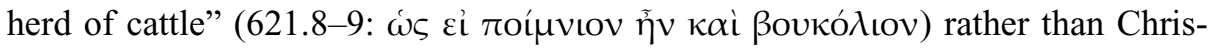
tians; Byzantine soldiers trapped in a gorge "were destroyed like herds of domes-

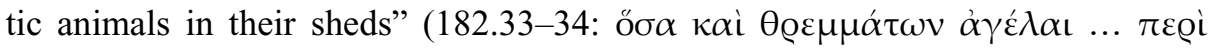

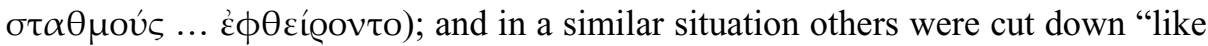

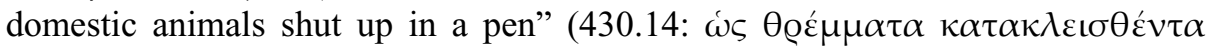
$\sigma \eta \kappa \tilde{\omega})$.

These animals occur also other than as prey. Thus for cattle Cumans returned home driving "their captives like herds of kine and yoked animals" (631.14-16:

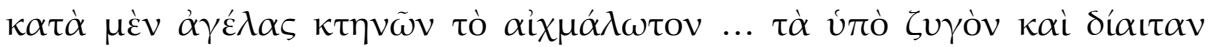
$\zeta \tilde{\omega} \alpha)$; while citizens turned aside from a rebuke from Alexios $\mathrm{V}$ as if it were "a

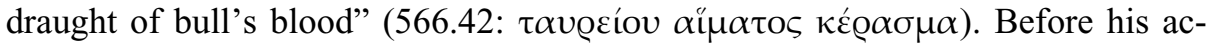
cession Isaac II knew that "the flesh-eating Andronikos would sacrifice him like

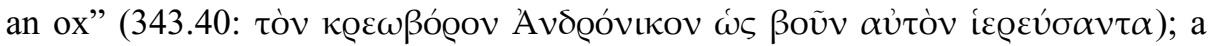
certain Vatatzes accused of adultery with Euphrosyne was "dismembered like a

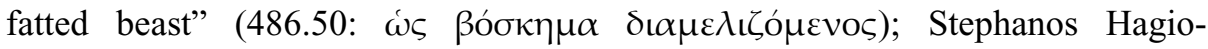

48 Noun and first adjective are taken from Luke 15.4.

49 Unadorned metaphorical use of the non-descript word for "prey" ( $\theta \dot{\eta} \varrho \alpha \mu \alpha)$ occurs at 96.54; $105.71 ; 191.11 ; 195.35 ; 296.86 ; 511.70$. See also 70.29; 288.55-57 quoted above, 234, 236 respectively. Nets for hunting (or sometimes perhaps fishing) occur in further similes or meta-

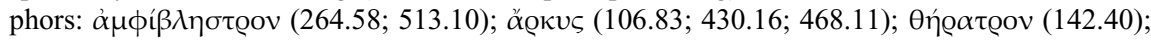

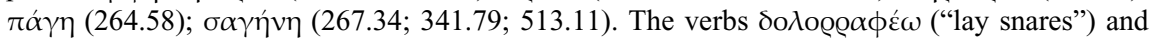

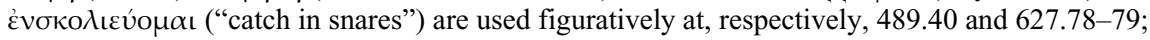
and the verbs $\dot{\varepsilon} \pi \iota \lambda \lambda \omega \zeta \omega$ and $\dot{\varepsilon} \pi \iota \omega \omega \ddot{v} \sigma \sigma \omega$ for hunters' calls are similarly employed at 392.67 . The word $\delta \varepsilon ́ \lambda \varepsilon \alpha \varrho$ ("bait") may pertain to hunting at 14.56 . 
christophorites was cut down by Isaac II "like a fatted beast in convulsions and

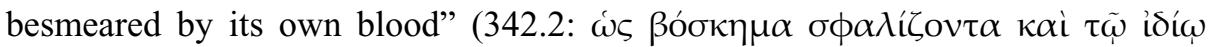
$\pi \alpha \lambda v v$ ó $\mu \varepsilon v o v \alpha i \mu \alpha \tau \iota)$ and those loyal to the emperor killed the rebel John Komnenos "striking blows all over his body as if he were a fatted beast" (527.67-68:

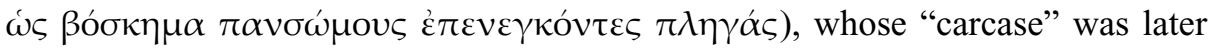

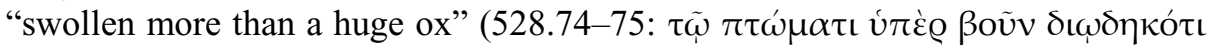
$\mu \varepsilon \gamma \alpha \lambda$ ó $\pi \lambda \varepsilon$ QOov). A quite different picture is conjured by John Kamateros

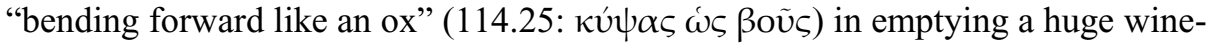
bowl to win a wager.

The Psalmist's tag "as sheep for the slaughter" (43.23: $\omega \varsigma \pi$ ๘ó $\beta \alpha \tau \alpha$ $\sigma \phi \alpha \gamma \tilde{\eta} \varsigma)$ occurs unadorned at 187.16, 338.86 and $432.64 .{ }^{50}$ Goats have more varied uses in Choniates. Both besiegers and defenders of cities, remarkably for once without variety of vocabulary, "bounded over precipices like wild goats"

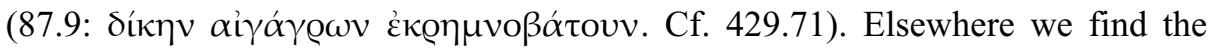
domestic kind. The lascivious Andronikos was like a billy-goat leading she-

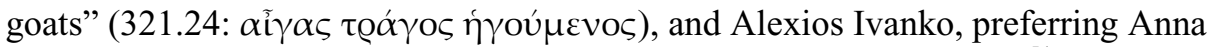
as bride to her daughter, asked "What have I to do with a suckling kid" for cover-

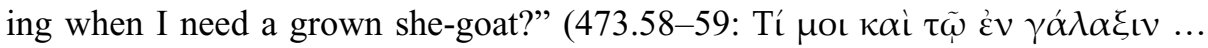

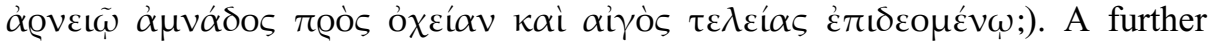
instance appears in a series of comparisons: "some [guardians of the young Alexios II] often wing their way in the manner of bees to the provinces and store up money like honey, and others like goats love the young shoots of empire ... and some imitating pigs grow fat on more sordid revenues ... rolling around in filthy deeds and rooting in the manner of pigs for everything that is most evil" (227.23-

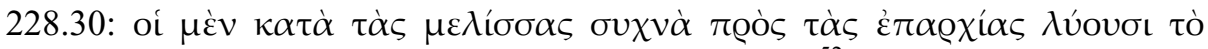

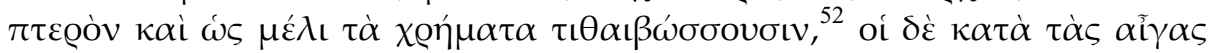

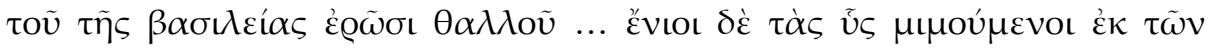

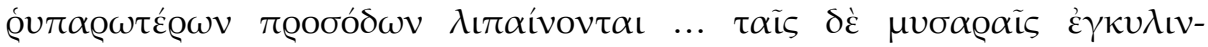

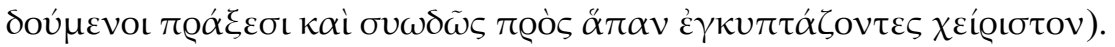

Pigs occur alone in the simple "swinish onrush and reckless crowd" (558.44-

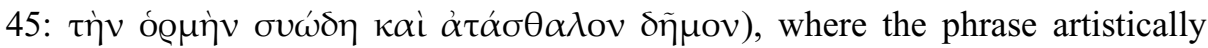
follows the removal of the statue of the Kalydonian boar in the Hippodrome. Vlach rebels also "rushed to the Danube like the herd of swine in the Gospels

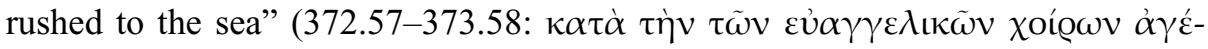

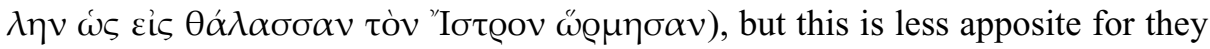
crossed the river safely while Saint Matthew's animals (8.32) perished. The Latin

50 The image of a shepherd of his flock is used for a patriarch ( $\alpha \varrho \chi ı$ เó $\mu \eta \nu)$ at 456.80; 522.30 and

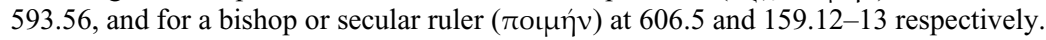

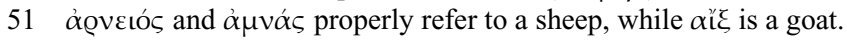

52 This verb is Homeric (Od. 13.106). 
patriarch Thomas Morosini was "in his bodily conformation fatter than a hog

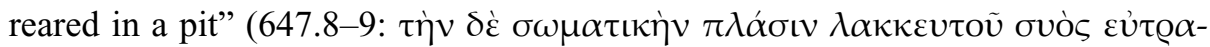
$\phi \varepsilon ́ \sigma \tau \varepsilon @ o \varsigma)$; Frederick Barbarossa contemptuously forced Byzantine envoys to sit together with servants "as swineherds drive the swine all together into a sty, with-

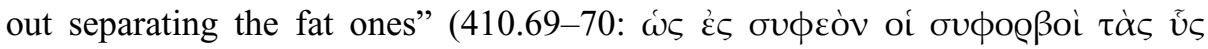

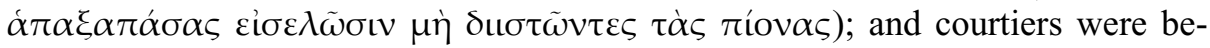
guiled by the empress Euphrosyne, "their ears tickled like pigs who lie supine

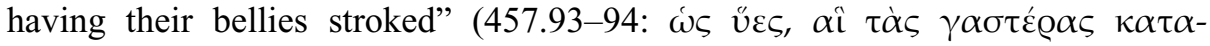

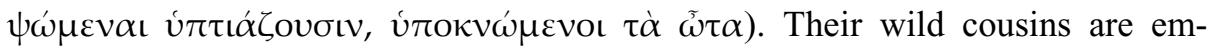
ployed four times: Armenians are described "unexpectedly urging themselves on just like, so to speak, a charging pack of boars" (26.73-74: عis $\pi \alpha \varrho \alpha ́ \lambda o \gamma o v \omega \varsigma$

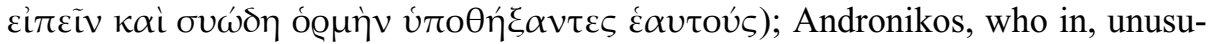
ally, a condensed version of Psalm 79.14, "wreaks destruction like a ferocious

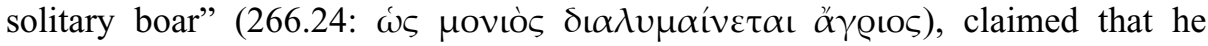
would destroy the enemy "in the manner of hunters [killing] boars that live soli-

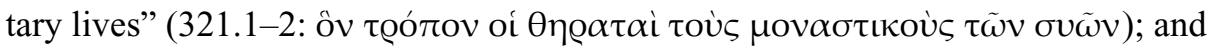
imperial soldiers in pursuing Alexios Ivanko were reluctant "to grope for tracks of an eagle flying over crags and mountains, or search for the creeping of a snake on a rock or enrage to close combat a tusked wild boar repeatedly exposing its breast

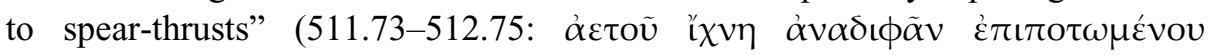

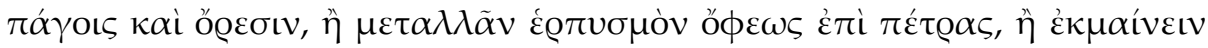

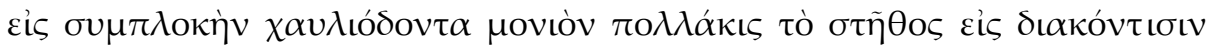

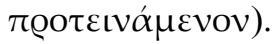

Equine similes usually concern eagerness and may involve chariot-racing. To encourage his rebellion in 1181 Maria, Byzantine wife of Renier of Montferrat, "by means of her letters spurred Andronikos on like a horse standing at the start-

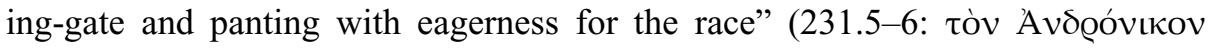

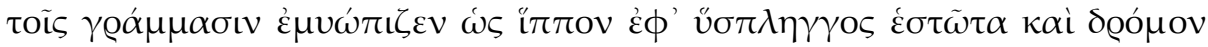
$\pi \nu \varepsilon \dot{o} v \tau \alpha$ ), although this was insufficient for later we learn of him "having been spurred on like a horse running in the hippodrome" (243.37: $\mu \nu \omega \pi \imath \sigma \theta \varepsilon i \varsigma \omega \varsigma$ i $\pi \pi \circ \varsigma \sigma \tau \alpha \delta\llcorner\varepsilon v \tau \eta ́()$ ) by words from his daughter Maria; and Byzantine and foreign tax-gatherers were sent out in the provinces in pairs by Manuel "like out-

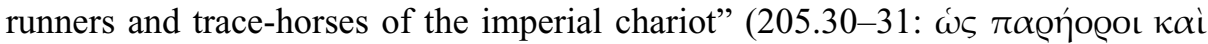

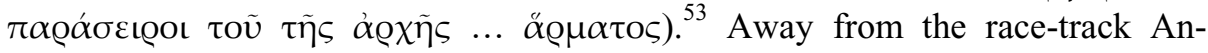
dronikos quenched his anger "like a mettlesome horse hard to restrain" (269.83-

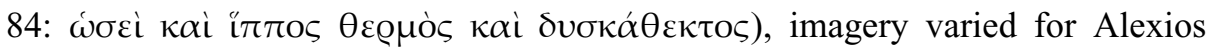

53 A further passage (437.16-23) compares Isaac to (a runner and) a charioteer, but, despite reference to bridle and reins, horses are not mentioned. Metaphorical use of bridle or reins is not uncommon (e.g. 17.33, 36.63-64, 103.5, 146.39-40, 343.35, 377.54, 437.20-21 [a small part of a noteworthy series of equestrian similes], 569.8-10). 
Branas "forcibly restraining and throttling his innate lust for power as if it were an

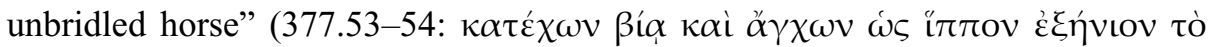

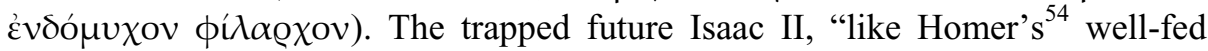
horse unable to stamp his hooves on untilled ground and rush over the plains with free foot ... imitates the war-horse pricking up his ears to the trumpet that sounds the battle-signal, tossing his mane, snorting and leaping" (342.82-86: $\mu \eta \dot{~ \varepsilon ́ \chi \omega v ~}$

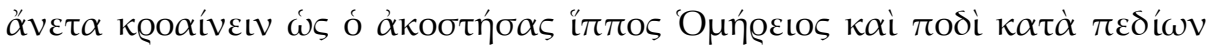

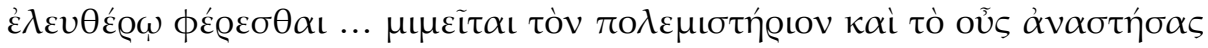

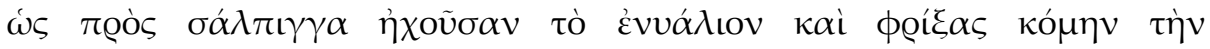

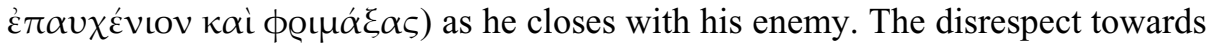
the emperor of the charlatan Basilakios is shown by his "racing hither and thither

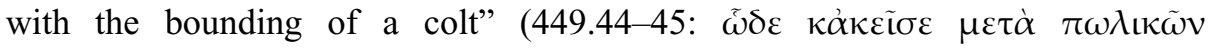

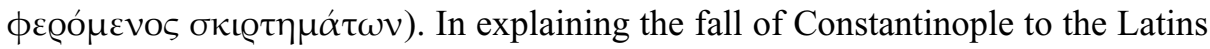
the historian avers that "God thought fit to pull tight on our jaws with muzzle and bridle because we had all turned away [from him] ... like a stiff-necked horse

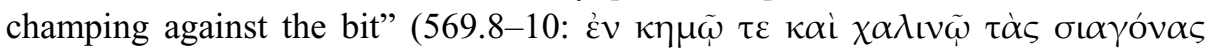

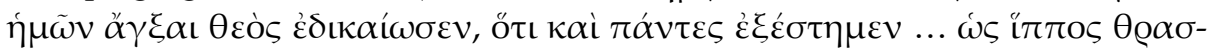

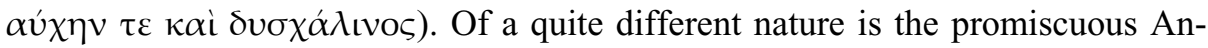
dronikos "like a horse in heat indulging in innumerable acts of copulation"

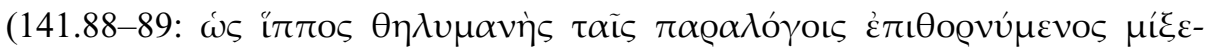
$\sigma \iota v)$.

The donkey, surprisingly, appears only once - for a lecherous Latin "braying

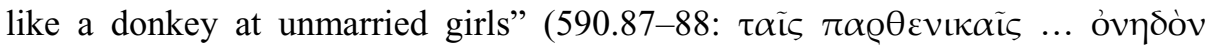
$\varepsilon \dot{\tau} \iota \beta \omega \omega \omega \mu \varepsilon v o \varsigma)$. The dog, on the other hand, is given varied uses. Theological

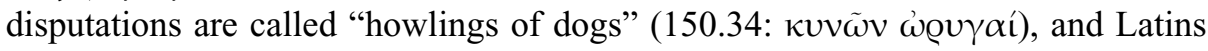

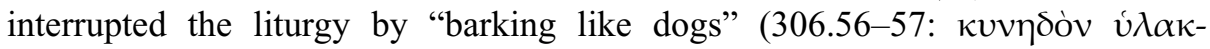
$\tau o \tilde{v} v \tau \varepsilon \varsigma)$. David Komnenos, the strategos at the siege of Thessaloniki, is critized because "he checked the fervour of the citizens like a totally useless hunter

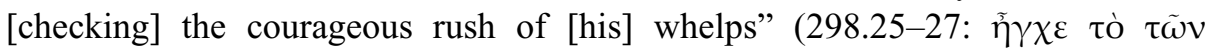

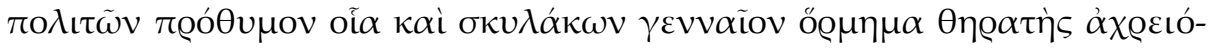

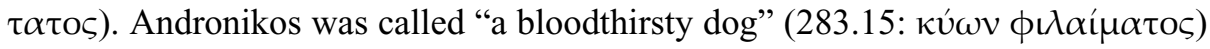
by the Nikaians, and later, in the absence of his real enemy, he turned his anger on those near by, "doing the same things as dogs are wont to do, for they, retreating from the one hurling [stones], ward him off with barking, but snap with their

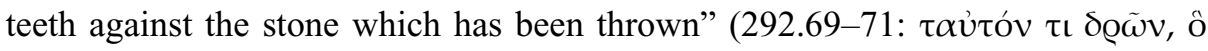

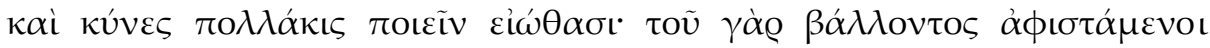

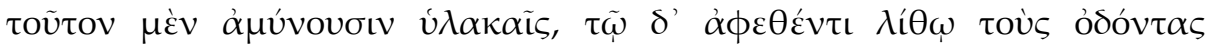
$\dot{\varepsilon} \gamma \chi \varrho i ́ \pi \tau o v \sigma \iota v)$. Slightly different canine behaviour is attributed to the inhabitants

54 Il. 6.506-507 (= 15.263-264). Van Dieten (see n. 5) adds Soph. El. 25, but the resemblance is slight. 
at the Latin sack of Thessaloniki for, "in the manner of dogs they retreated from those who overtook them and did not molest them with their teeth, but as they were being hard pressed gave up barking at those before whom they crouched

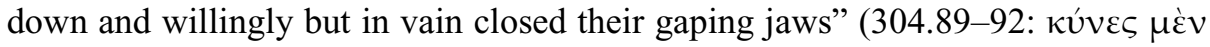

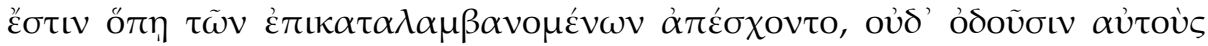

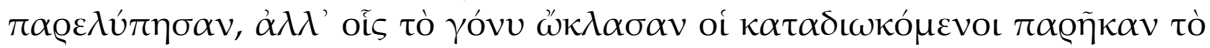

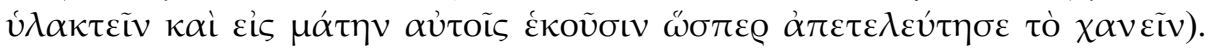
Andronikos possesses another canine quality when Choniates accuses him of

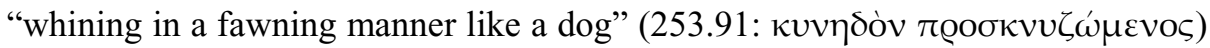
in front of the patriarch Theodosios Boradiotes. Another aspect of fawning appears twice: two disaffected Byzantines came close to "licking with their own

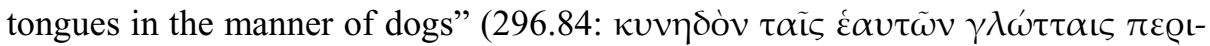
$\lambda \iota \chi \mu \alpha \dot{\alpha} \zeta \varepsilon v)$ the feet of William II of Sicily; and courtiers prostrate before Euphrosyne "thrust their noses against her slipper like fawning puppies" (456.87-

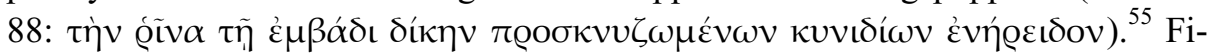
nally Choniates borrows from Psalms (58.15) for Andronikos who, "famishing like a dog, to quote David, would wander around the city for want of someone to

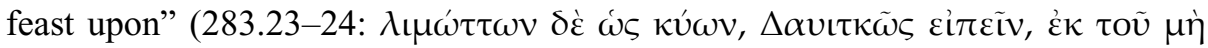

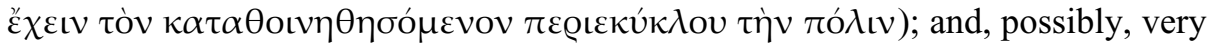
briefly from Sophokles (Aj. 8) for the rebel Andronikos Lapardas' decision to

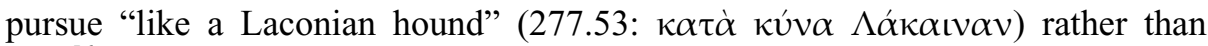
flee. $^{56}$

Deer are used not unsurprisingly as examples of both pusillanimity, the strategos David Komnenos being castigated as "more cowardly than deer"

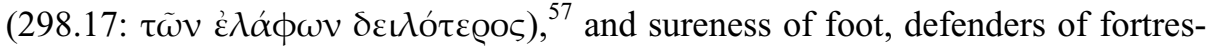
ses being, in a phrase drawn from Psalms (17.34), "like deer setting their feet on

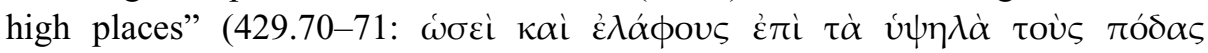
$i \sigma \tau \tilde{\omega} \nu \tau \alpha \varsigma)$. A further quite different passage probably refers to this animal upon the alleged adultery of his wife some counsellors advised Alexios III what to do to avoid becoming subject of common gossip and "being compared with those animals that have defences breaking forth from their heads but are never provoked and who do indeed not use their horns against those who cover their

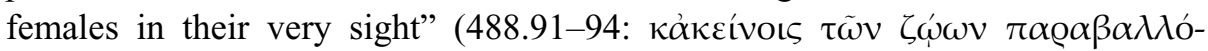

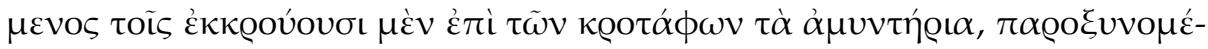

55 This is just before they are transmogrified into pigs at 457.93 (above, 240).

56 Though it is not strictly a simile or a metaphor, note may be taken of Dositheos suffering "exactly the fate of Aesop's dog" (Fab. 136) in losing the patriarchates of both Jerusalem and Constantinople (407.82-85).

57 Cf. their avoidance of lions at 561.21, quoted above, 237. 


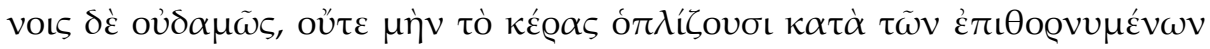

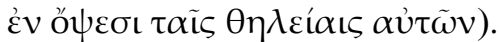

Other wild mammals appear only fleetingly. Constantine the Armenian charged at Eustratios the Macedonian like "a mountain-bred gazelle bounding

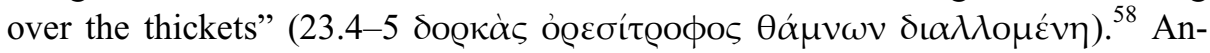
dronikos went round "like a she-bear bereft [of her young]" (283.24: $\omega \varsigma$

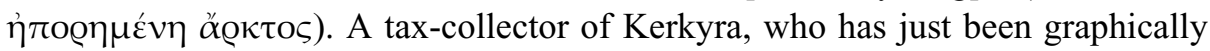
described as "smoother in cunning than a pestle", is called a "fox" (73.7: $\dot{\alpha} \lambda \omega \pi \eta \xi) .{ }^{59}$ Paronomasia aided John Lagos to disappear "surpassing a hare in

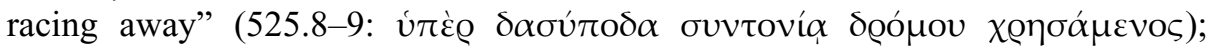
while in anticipation of Andronikos the Nikaians "cowered like leverets"

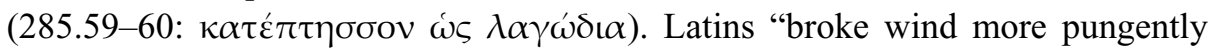

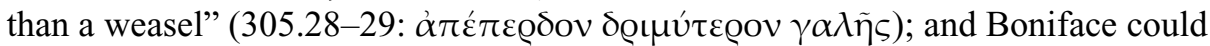
not keep his intentions secret for he was "comparable to the wease ${ }^{60}$ which was

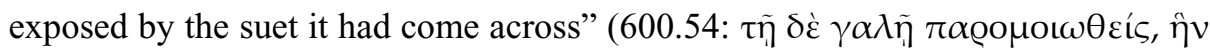

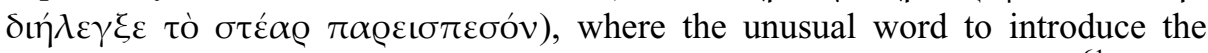
comparison was presumably chosen as a pun on the proverb $\left(\pi \alpha \varrho \circ \mu i^{\alpha}\right)^{61}$ that is its source. The emperor Isaac becomes a whale, ${ }^{62}$ an elephant and a camel ${ }^{63}$ in the metaphors of Mesopotamites as a "so-called pilot[-fish]" guiding "the whale"

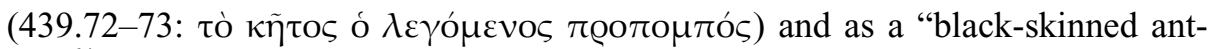
$\operatorname{man}^{64}$ steering an elephant, the greatest burden on the earth, or a slender rope

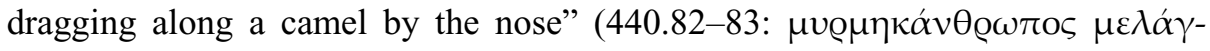

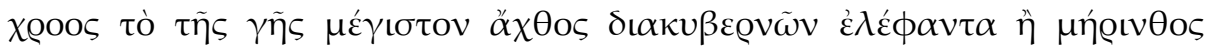

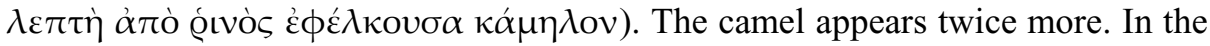
first instance, following Matt. 23.24, flatterers and evil judges "strained off the

58 Proverbs 6.5 is quoted virtually verbatim for Andronikos fleeing from the Vlachs "like a gazelle from the noose and a bird from the snare" (131.5-6).

59 For the skins of the lion and the fox see above, 237.

60 The Greek word $\gamma \alpha \lambda \tilde{\eta}$ ( $\gamma \alpha \lambda \varepsilon \dot{\eta})$ embraces a variety of mustelidae. Perhaps the marten or, more likely, the polecat is intended here. There are also two similes $(183.66 ; 425.64)$ involving a trap for a weasel $(\gamma \alpha \lambda \varepsilon \alpha ́ \gamma \rho \alpha)$.

61 A combination of Zen. 2.93 and 2.79.

62 The word used need not mean specifically a whale, but that is most likely in this context. David

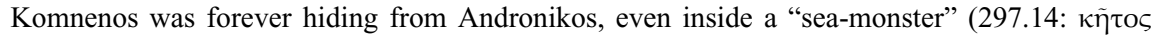

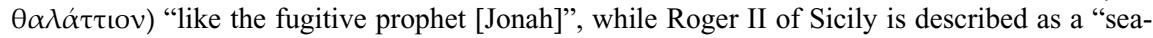

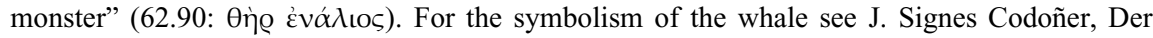
Historiker und der Walfisch. Tiersymbolik und Milleniarismus in der Kriegsgeschichte Prokops, in: L. M. Hoffmann/A. Monchizadeh (eds.), Zwischen Polis, Provinz und Peripherie. Beiträge zur byzantinischen Geschichte und Kultur (Mainzer Veröffentlichungen zur Byzantinistik 7), Wiesbaden 2005, 37-58 (I am indebted for this reference to Michael Grünbart).

63 For him in the same context but as a lion bothered by a bee and a mosquito see below, 254.

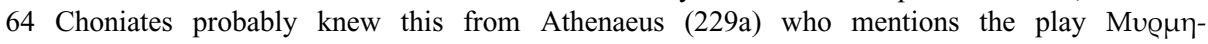

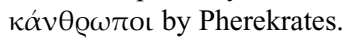




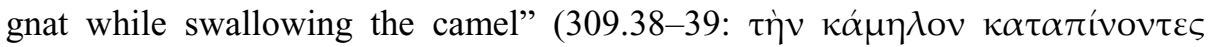

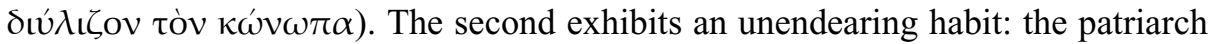
Theodosios Boradiotes concealed the truth from Andronikos since he was unwilling "to open the camel's mouth for it to spit as is its wont" (254.15-16: $\tau \dot{\eta} v$

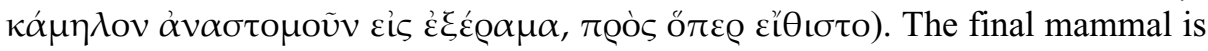
the dolphin like which the deep-drinking rebel John Komnenos is pictured "spouting" (527.50: $\kappa \alpha \tau \dot{\alpha} \delta \varepsilon \lambda \phi i ̃ v \alpha \varsigma \dot{\alpha} v \alpha \phi v \sigma \tilde{\omega} v)$.

Generic birds are put to various uses. Cumans and Vlachs, wheeling in battle after a feined retreat, "surpassed birds cleaving the air" (397.95: $\omega \varsigma$ oủd $\pi \tau \eta \eta \dot{\alpha}$ $\tau o ̀ v ~ \alpha \dot{\varepsilon} \varrho \alpha \tau \dot{\varepsilon} \mu \nu o v \tau \alpha)$; Latins "lighted upon Epidamnos like birds and rapidly stretching astride their feet from above scaled the battlements of the encircling

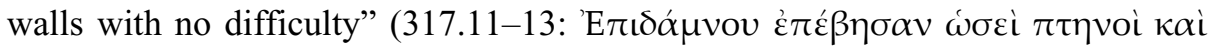

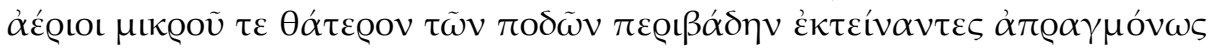

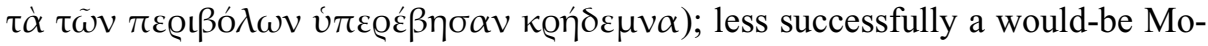
hammedan aviator, standing on a tower and raising his arms as wings, "shakes himself like a bird, thinking that he is walking on air" (120.77-78: $\delta \mathrm{i} \alpha$ -

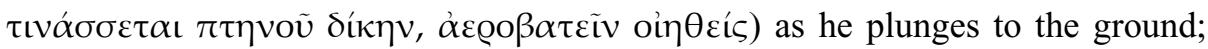
Isaac Komnenos, when incarcerated on orders of his younger brother Manuel,

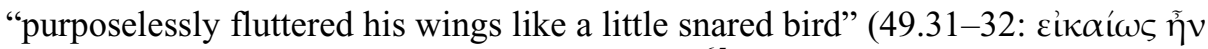

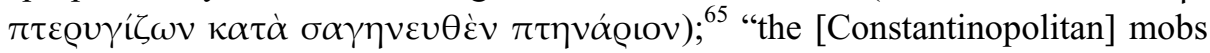

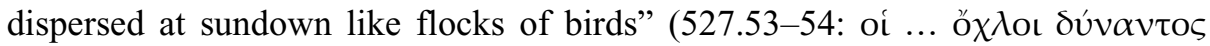

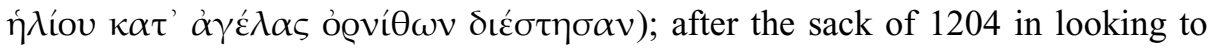
elect an emperor "some [Byzantines] like birds among living creatures fly away and depart together in a flock to this man, but others select prickly shrubs for

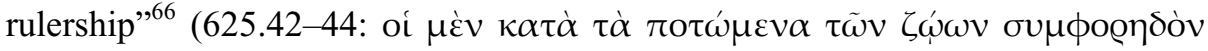

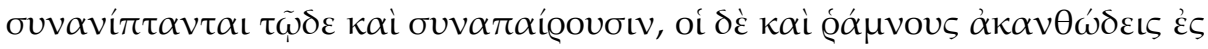

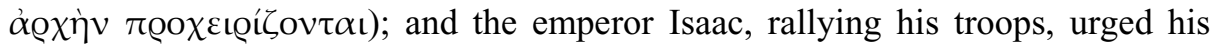
men not to change sides during the battle "as we see happen with birds flying in flocks, for when one flies away the remainder also fly off together with a whirring sound, and upon one coming to rest the others fold their wings" (385.57-59: ô

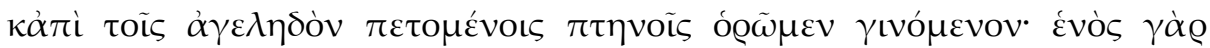

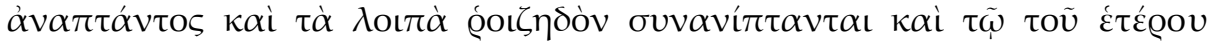

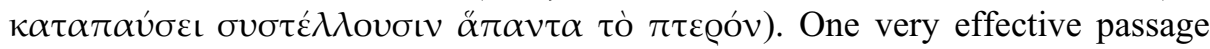
does not even use a regular word for "bird": the Latin host "outstrips my narrative and rushes on with faster flight than the quill of my history ... and like ... a winged and aerial creature flying beyond the history it advances towards the

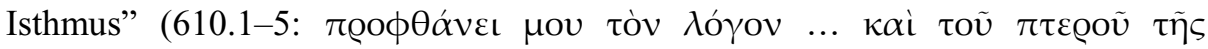

65 See also n. 58.

66 This last part comes from Iud. 9.14. 


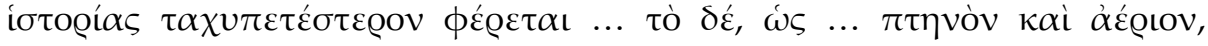

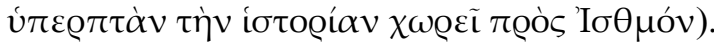

The generic word ópvı occurs in a repeated Biblical image, ${ }^{67}$ first and at its simplest when men of rank pitched their tents around Andronikos "in the same manner as mother-birds draw their wings over their chicks" (255.36-37: ôv

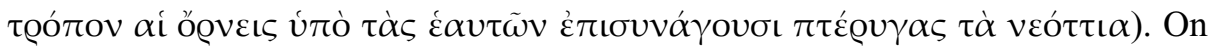
two subsequent occasions it occurs in more extensive avian imagery. On one, although the Latin conquerors were "birds with crooked talons flying almost in the clouds and hovered oppressively over the Byzantines at that time in their

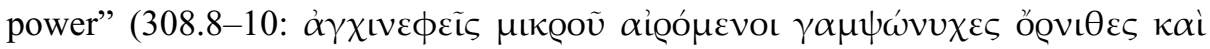

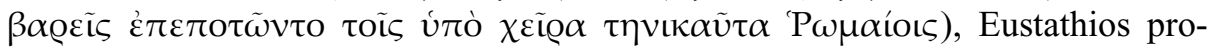
tected them "as a mother-bird spreads her wings around her chicks" (ibid. 12-13:

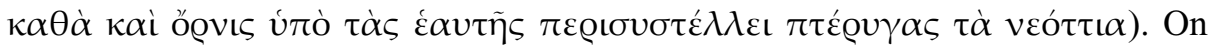
the second Choniates laments the sack of 1204 and plaintively asks when Constantinople will once more be able to gather her children together "as motherbirds which love their offspring gather their own chicks beneath their wings"

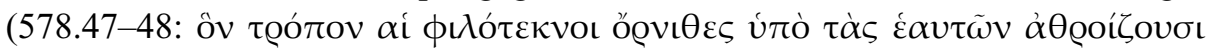

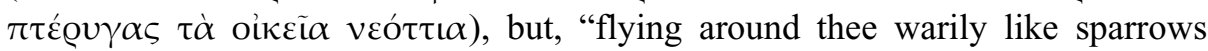
whose nurturer has been captured and whose nest has been scattered we utter

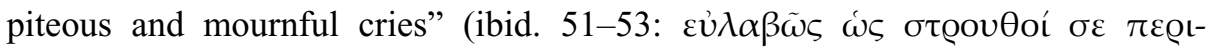

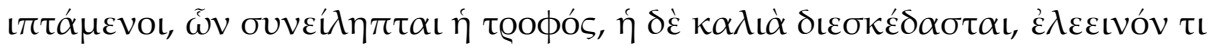
$\kappa \alpha i$ $\gamma 0 \tilde{\omega} \delta \varepsilon \varsigma \alpha \dot{\alpha} v \alpha \beta \alpha \lambda \lambda o ́ \mu \varepsilon \theta \alpha$ ), and are "borne along roving far and wide like

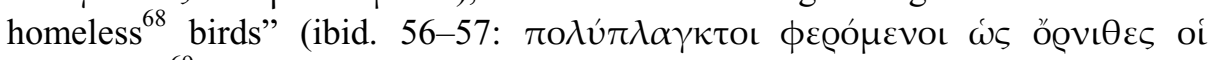
$\dot{\alpha} \beta \varepsilon \hat{\varepsilon} \beta \iota \iota){ }^{69}{ }^{6}$ Similar imagery connected with this event had occurred earlier in Choniates' version of Isaiah 10.14 with Sicilians boasting that they would seize the Empire "as a deserted nest" and "abandoned eggs" (304.1-2: ws ह̌

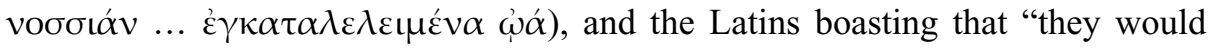

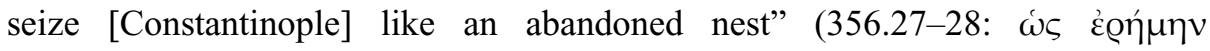

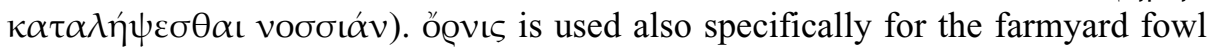
in a comparison for Andronikos with his wenches "leading his domestic hens like

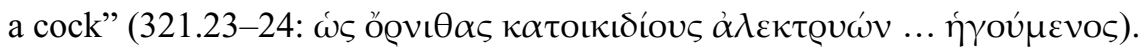

The most common avian imagery in Choniates depends upon the birds' cries, especially those of corvidae. Supporters of Andronikos on one occasion "cried ineffectually like jackdaws to a cloud-dwelling eagle with crooked talons"

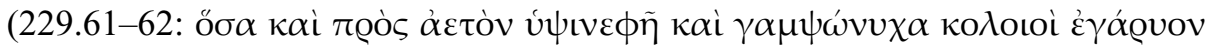
$\not \check{\kappa} \kappa \rho \alpha v \tau \alpha$ ), while on another they "enthusiastically winged their way to the queen

67 Matt. 23.37.

68 "Homeless" (i.e. "of no fixed abode"), rather than "unfirm" or "fickle", is probably the significance of Choniates' epithet. Magoulias translates as "migratory".

69 The avian imagery is interspersed with that of planets and probably that of cattle. 
of cities and ... croaked like cawing crows at the eagle [Alexios Komnenos]

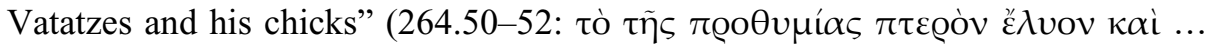

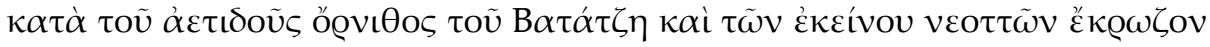
$\omega \varsigma \kappa о \varrho \tilde{\omega} v \alpha \iota \lambda \alpha \kappa \varepsilon \dot{\varrho} \cup \zeta \alpha \iota)$. The Latin conquerors of Thessaloniki were not moved by tears, even a pleasant word being considered as "screaming of kites or cawing

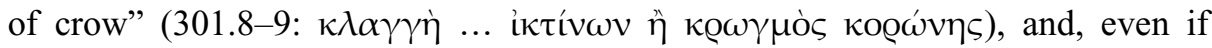
momentarily successful, it rapidly became "a swan's dying and honour-loving

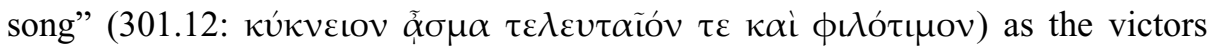
returned to slaughter. As artisans from Constantinople fell upon the Latins "their unintelligible cries filled the air just as if flocks of jackdaws, cranes or starlings

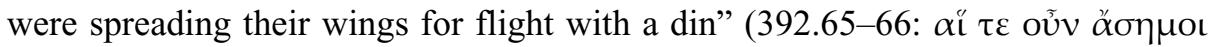

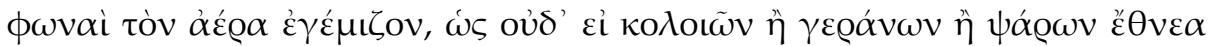

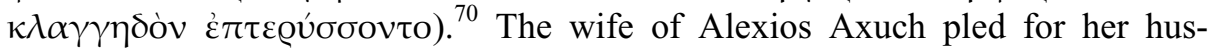
band's life "more piteously than a lammergeyer (?), more grievously than ser-

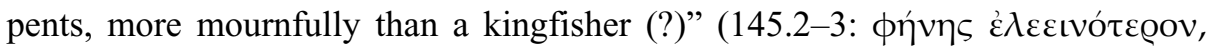

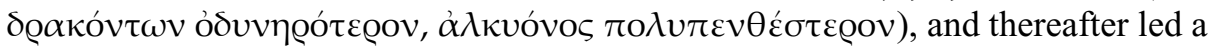

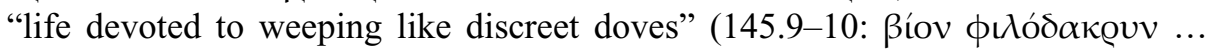

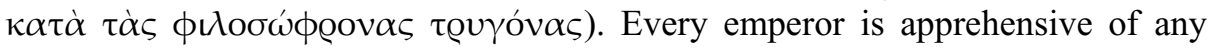
man who "has been furnished with a mouth and tongue like a nightingale"

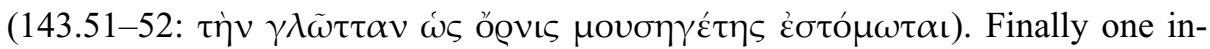
terpretation mentioned by the historian for the prophecy "Oh, thou wilt become

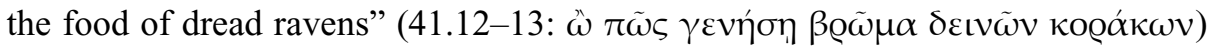

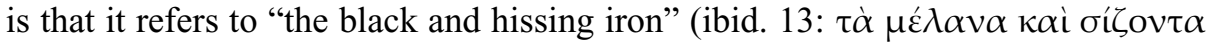
$\sigma \iota \delta \eta \dot{\rho} \alpha)$ of cauterization.

For other images the eagle is most often used: John II, dying after his accident hunting, bewailed the fact that he could not now "fly like the kings of birds"

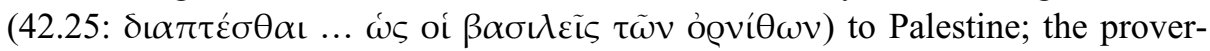

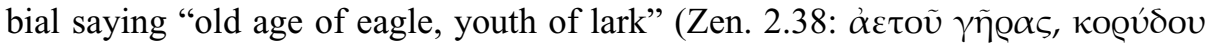

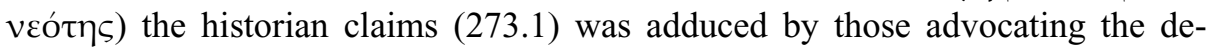
thronement of Alexios II; and the comparison of tracking Ivanko and a highflying eagle has already been seen. ${ }^{71}$ In a metaphor for Stephanos Hagiochristophorites "the hawk (?) was already poised and the seizing [of its prey, Isaac] was

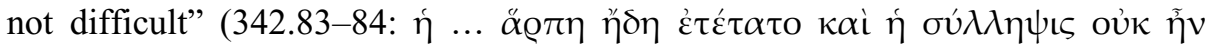

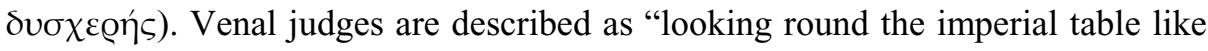

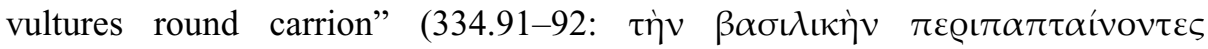

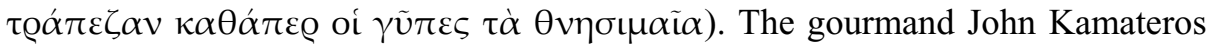

70 This is a combination of Hom. Il. 2.459-463 and 16.583 or $17.755-756$.

71511.73 , above, 241. 
"consumed fields whole or, more accurately, attacked them like a thoos",72

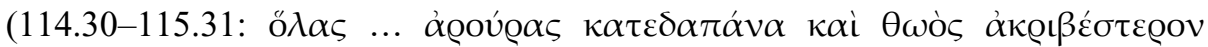

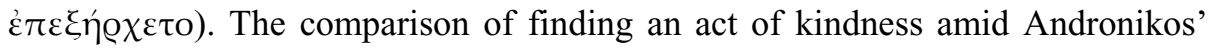
evil deeds and "setting before oneself a tasty banquet of starlings and quails" has already been noted. ${ }^{73}$ The archetypal avian beauty, the peacock, appears twice: Franks prided themselves because "they are [not] gilded with purple and gold like

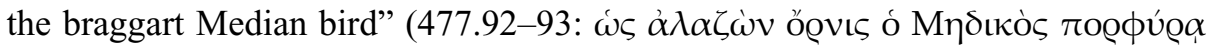

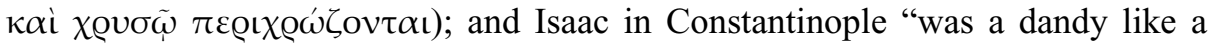

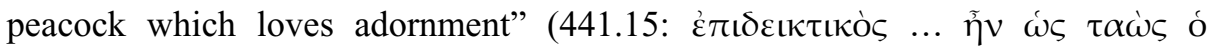

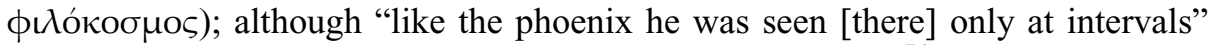

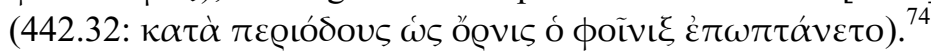

Choniates evinces little ichthyic interest or knowledge. ${ }^{75}$ Conspirators, deprived of the right to answer charges, were led off to prison "like speechless fishes" (232.29: $\omega \varsigma$ ó $\phi \omega v o r ~ i \chi \theta v ́ \varepsilon \varsigma)$. Only two are specifically named: Andronikos "escaped the hand of all [his foes] like a slippery eel" (138.23-24: $\omega \varsigma$...

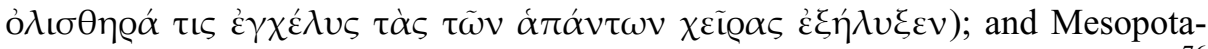
mites, as we have seen, guided the imperial whale like a so-called pilot-fish. ${ }^{76}$ Nevertheless, two marine mollusks make an appearance, the first a cephalopod (in the first two passages certainly the octopus). Uncertain of his hold on the throne, John II did not attend his father's obsequies, but "clung to the palace like octopo-

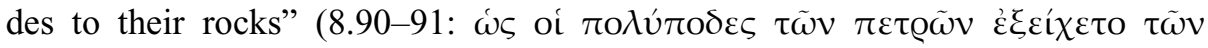

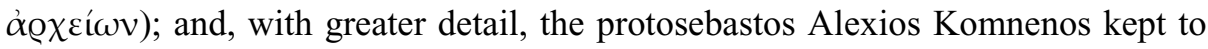
the imperial apartments "like an octopus clinging tightly to the rocks with its

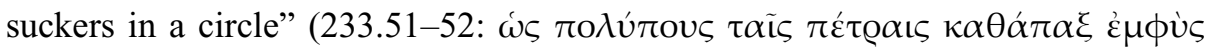

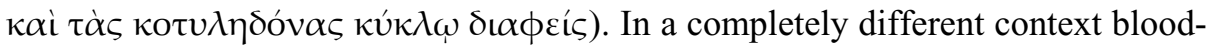
relations turned away from Alexios V Mourtzouphlos' harsh words "as if from a

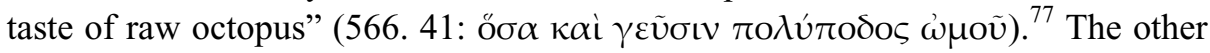
mollusk appears when witnesses of the death of Manuel, who was clad in but a tattered garment, reflected on "the wretchedness at the end of life of the body,

72 Hesychios' entry for this bird is simply ópvıs rotós. Choniates' context suggests that it fed on grain.

73 324.10-11, above, 228-229.

74 The context of Choniates' quotation of Ps. 146.9 at 593.66-67 makes his use of nestling ravens arguably metaphorical.

75 There are a few images of fishermen (56.49-57.52; 341.79-80 and possibly 244.64) and a fisherman's bait ( $\delta \varepsilon \lambda \eta ́ \tau ı v ~ a t ~ 57.51 ; 226.80)$, while some of the passages involving metaphorical nets listed in $\mathrm{n} .49$ above may pertain to fishing rather than hunting.

$76439.72-73$, above, 244. Although there is no word for "fish", o $\lambda \varepsilon \gamma$ ó $\mu \varepsilon v o s$ indicates that

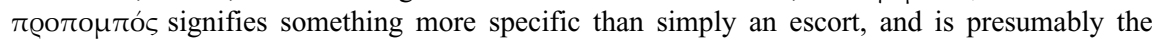
type of fish mentioned by Aelian (de Anim. 2.13).

77 Andronikos' wish for the sexual appetite of an octopus (322.33) is not so much a metaphor as a piece of zoological lore. 
which is moulded around us like an oyster and grown together with the soul"

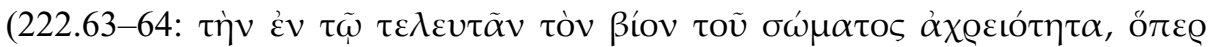

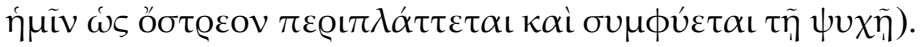

Two reptiles receive one mention each. In a metaphor for Desa, the deceitful Serbian župan, "the chameleon, although it easily changed to every other colour,

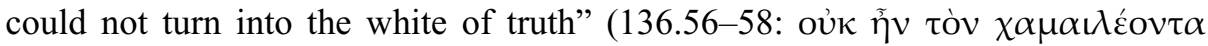

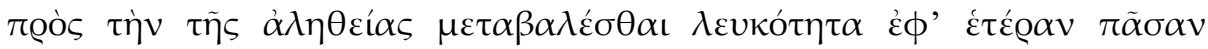

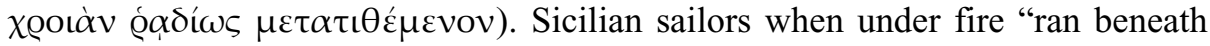

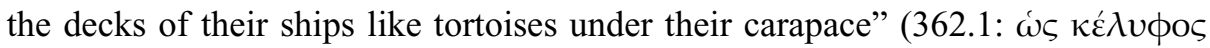

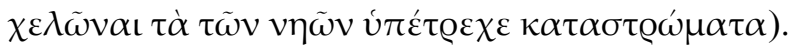

Snakes, on the other hand, figure no fewer than 33 times. Although normally

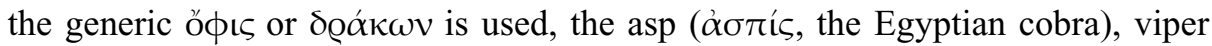
( $\chi_{\llcorner}\llcorner\delta \vee \alpha)$ and "javelin-snake" ( $\left.\dot{\alpha} \kappa o v \tau i ́ \alpha \varsigma\right)$ are also found.

The Bible inspires many references. Without attempt at quotation Choniates refers to the serpent in Genesis for three passages: finding good in Andronikos was "like hunting for and finding a highly prized panacea and salutiferous anti-

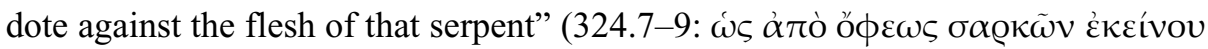

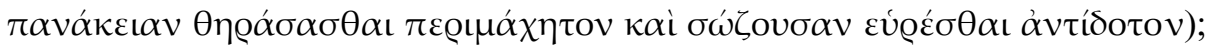
"foreigners [Latins] as treacherous as the serpent" (592.35: غ̇ $\pi i \beta$ ß $\alpha \lambda \lambda$ ó $\phi v \lambda$ o $)$ made the conquered Byzantines wear fig-leaves and rags; Skleros Seth, having seduced a girl with a peach, ${ }^{78}$ was regarded by her kin as one who "like the serpent, the author of evil, despoils maidens by means of fruits and

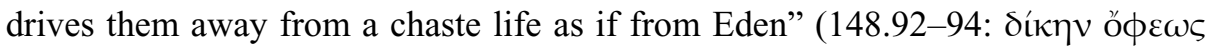

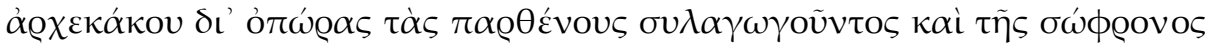

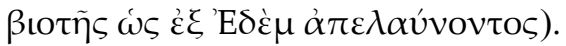

The same serpent cloaked in the language of other Biblical passages occurs elsewhere: with a nod to Eccl. 10.11 John Kamateros was "possessed of a forked

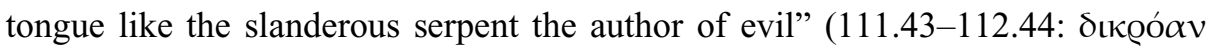

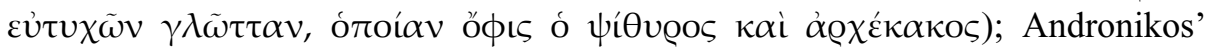
widespread executions would have been carried out "had not God, in the words of the prophet, ${ }^{79}$ brought down his own sword on the apostate serpent, the crooked one, the one that flees beneath the waters, his wet abode" (338.89-91: $\varepsilon \dot{\imath} \mu \dot{\eta} \kappa \alpha \tau \dot{\alpha}$

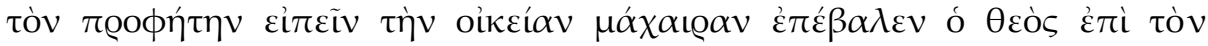

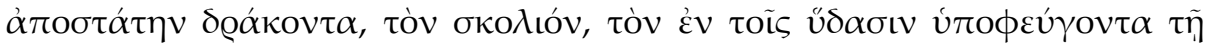

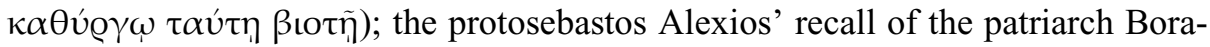
diotes to Constantinople is graphically described in a long extension of its prece-

78 This was presumably a simple gift of affection, but fruits with seeds were considered to promote fertility (see above 229 and n. 24).

79 Is. 27.1 . 
dent: ${ }^{80}$ "so against its will the crooked serpent uncoiling itself and swallowing down again its venom, which it had prepared to vomit over the holy man, gives its approval for this man's return to his former throne" (242.16-19: äk $\omega v$ oũv ó

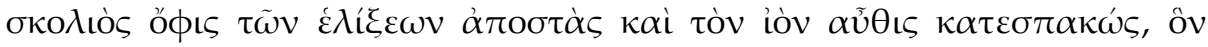

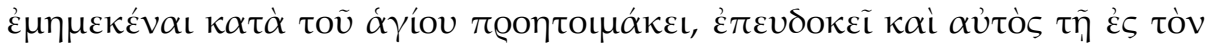

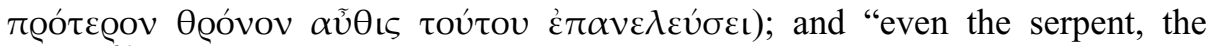
ancient ${ }^{81}$ plotter against the human race did not of old conceive and give birth to"

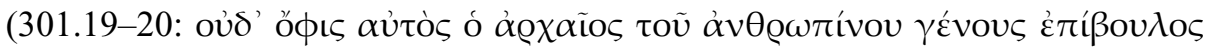

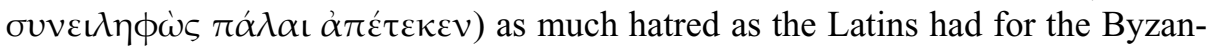
tines.

The famous deaf asp ${ }^{82}$ of Psalms 57.5 is given employment, with far less variety of vocabulary than is Choniates' wont, on four occasions for refusals to harken: John II "was incanting these things to asps [inhabitants of a besieged fortress in Cilicia] deliberately making themselves deaf to the beguiling melodies

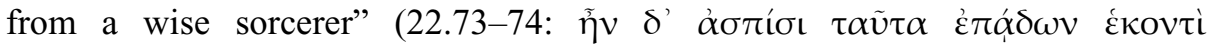

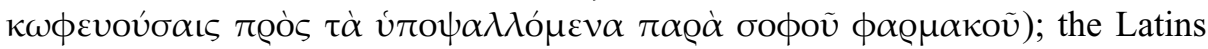
in their refusal to listen to proposals for peace "ignored every wise sorcerer like

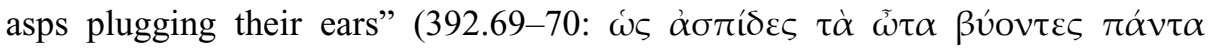

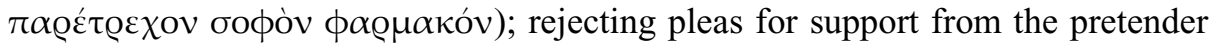
Isaac Doukas Komnenos the Turks "all like asps blocked up their auditory organs

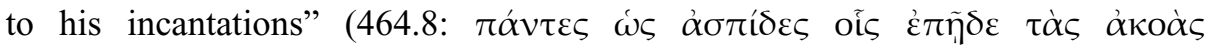

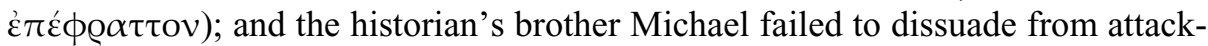
ing Athens Leon Sgouros whom "he saw deliberately plugging his ears like an

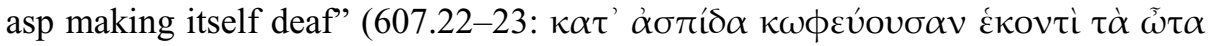

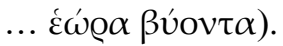

Choniates uses four further Biblical serpents: men rejoiced at the fall of Mesopotamites as if "the serpent that was not caught by Job ${ }^{83}$ had been seized"

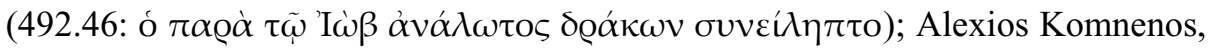
son of the protovestiarios John, escaped from the Cumans "one would say like a

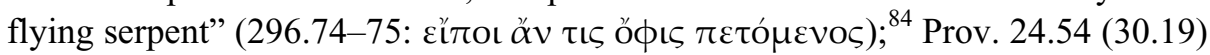
lies behind the pursuit of Ivanko being paralleled to the "tracking of the creeping of the serpent on the rock"; ${ }^{85}$ and one passage from Psalms surrounds a tag from

80 Noun and adjective alone come from Soph. 16.5 or Is. 27.1.

81 This may be a fleeting remembrance of Apoc. 12.9.

82 Although the translation adder is hallowed by the King James' Bible (Ps. 58.4), the word, as its primary significance of a round shield suggests, indicates the species as the (Egyptian) cobra or asp (Coluber haié).

83 See Iob 40.25 .

84 This is probably a reminiscence of Is. 14.29 .

85 For the Greek of the whole series of comparisons see above 241. 
Homer ${ }^{86}$ when at the siege of Zeugminon the Hungarians "whetted their tongues like a snake's ... letting fly from the barrier of their teeth obscenities smeared with the venom of asps that is under their lips" (133.67-69: $\tau \dot{\alpha} \varsigma \gamma \lambda \omega \sigma \sigma \alpha \varsigma$

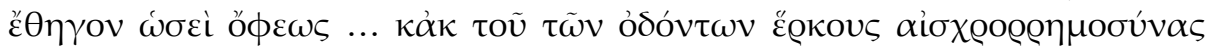

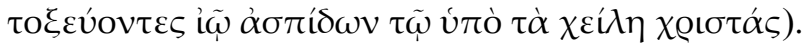

The myth of the Hydra inspires similes. The first is very simple: Manuel's thoughts, undeterred by disasters, were forever "growing again like the Hydra" (160.25: $\pi \alpha \lambda \iota \mu \phi \tilde{\eta} \kappa \alpha \tau \dot{\alpha} \tau \dot{\eta} v^{~ " \Upsilon \delta \varrho \alpha \nu) . ~ T h e ~ s e c o n d, ~ n o t ~ s t r i c t l y ~ a ~ s i m i l e ~ o r ~}$ metaphor, is put into the mouth of Andronikos who, in justification of his execution of prisoners, asked "What benefit is there, when one head is cut off, that more will grow, and that there is no man to apply the sizzling iron? Herein the demigod and hero Herakles is especially to be praised because he had Iolaos to

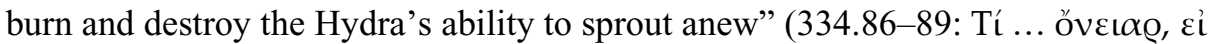

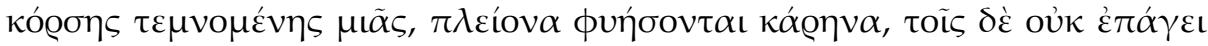

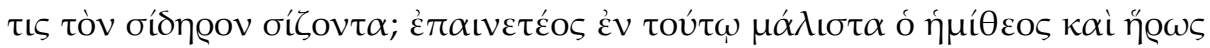

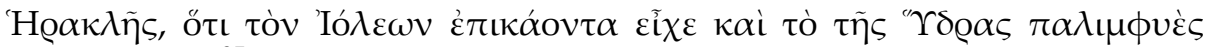
$\dot{\alpha} \phi \alpha v i$ 'ov $\tau \alpha){ }^{87} \mathrm{~A}$ second myth is obscure: the state of the Empire is likened to "that of the mythical snake which wreaked havoc as it dragged itself along with maimed and damaged [literally deaf and blind] hindmost part" (225.48-50: тò

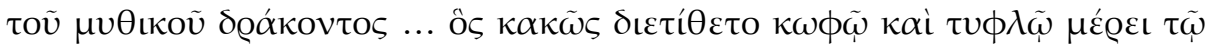

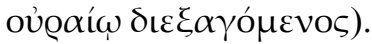

A fable of Aesop (Fab. 62) is used twice to illustrate treachery: Andronikos is compared to "the snake that will attack barely after being warmed and will do ill

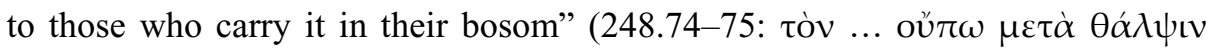

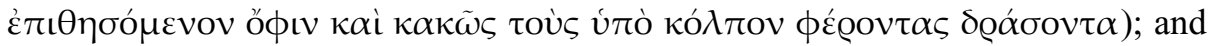
in respect to Isaac Doukas Komnenos the historian asks "who ... has befriended a venomous snake without it soon after, ${ }^{88}$ even if he has become attached to it, disgorging its venom and, even if he has warmed it in his bosom, giving him a

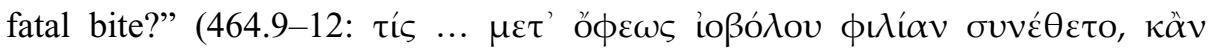

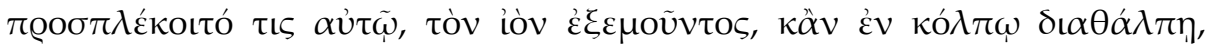

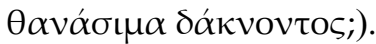

More independently Choniates rather awkwardly combines two images in claiming that Kilij Arslan, "like a torrent in full flood or a snake that had de-

86 Ps. 139.4 and Il. 4.350 etc.

87 A third mention of the Hydra does not, at least overtly, involve serpentine imagery but rather a comparison with Herakles, whose sexual powers were greater than those of Andronikos, although a parallelism between deflowered maidens and severed heads is probably intended

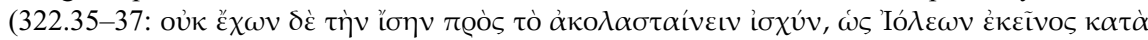

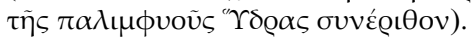

88 A few words have been supplied here from the Greek of an earlier part of a composite comparison (464.9-10) already quoted above, 234. 
voured many herbs, ${ }^{89}$ deluged and swept away whatever happened to be in his way and swallowed up many of our forts, spitting out the venom of its evil; but [Manuel] ... with the lure of seductive gold lulled it to close its eye-lids in peaceful sleep, and as it angrily reared up to plunder he soothed and calmed its coils

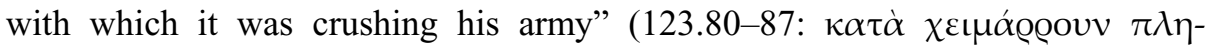

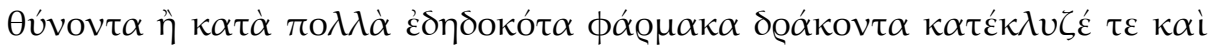

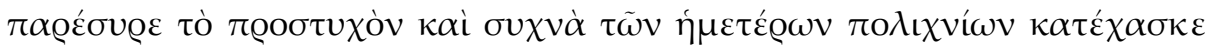

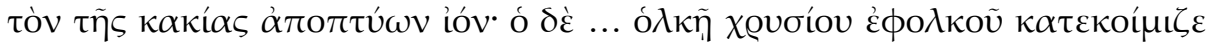

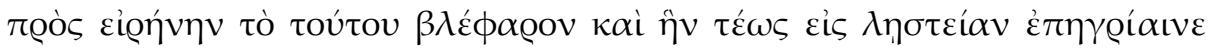

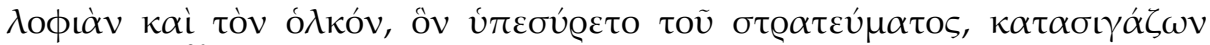
غ̇T@áüvev). ${ }^{90}$

Choniates has greater artistic success with other comparisons that are dependent upon anguine behaviour and appearance. Hungarian and Byzantine "armies seethed like an undulating ${ }^{91}$ snake with bristling scales" (156.21-22: $\kappa \alpha \tau \dot{\alpha}$

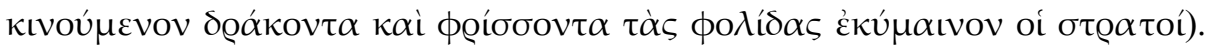
The Byzantines saw the Crusaders as, "like a flaming serpent, bending back with the coils of their troops, bristling with the scales of their weapons and opening out

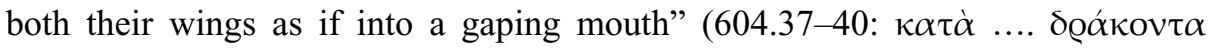

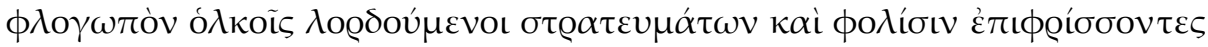

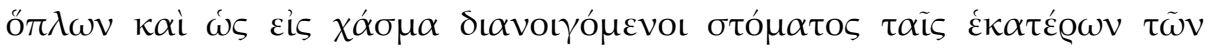
$\kappa \varepsilon @ \alpha ́ \tau \omega \nu \alpha \dot{\alpha} \alpha \pi \tau \dot{\xi} \xi \varepsilon \sigma \iota)$. The Turks thought that if they could overcome the main body of Manuel's army they could easily disable the rest "as we see happen with a snake, for when the head has been crushed the remaining coil of its body is

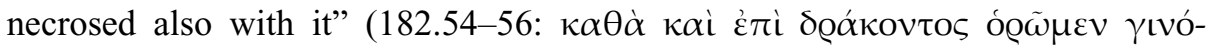

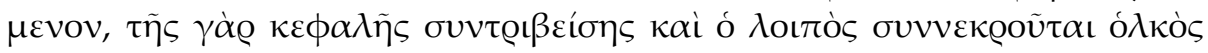
$\tau o \tilde{v} \sigma \omega \mu \alpha \tau o \varsigma)$. A comet may resemble the reptile, "for the sight of the visible fiery mass portrayed the shape and curling of a snake as it was now stretched into a straight line and now was twisted round into coils, and at another time opening into a chasm of a mouth it created fear in those that gazed at it as if it were gaping

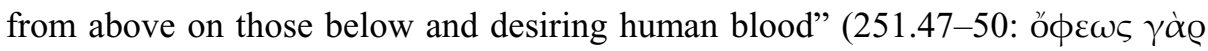

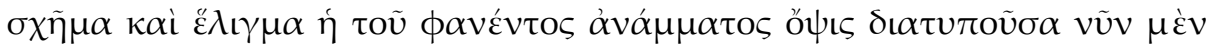

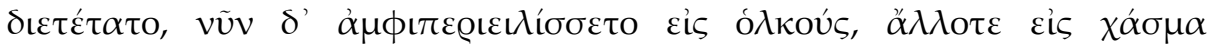

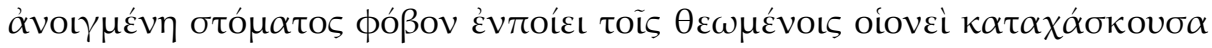

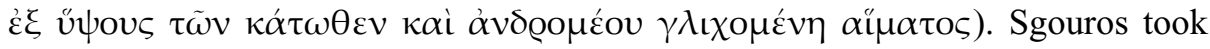
refuge on Akro-Korinth "as a creeping snake squeezes into a hole" (611.28: $\omega \varsigma$

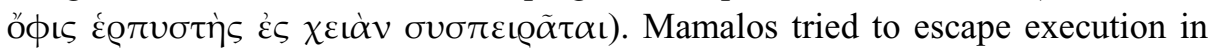

89 This part of the description is based on Il. 22.93-94.

90 This is necessarily a very loose translation. The omitted portion continues the image of the torrent.

91 An English translation is happier with the transference of marine imagery from armies to reptile. 
the Hippodrome by darting out of the flames "like javelin-snakes" (311.83: $\kappa \alpha \tau \dot{\alpha}$

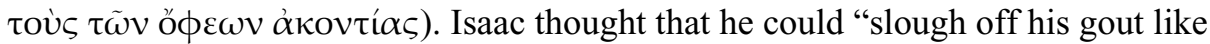
a snake-skin and be completely transformed into a god-like man" (558.30: $\omega \varsigma$

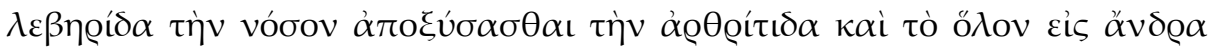

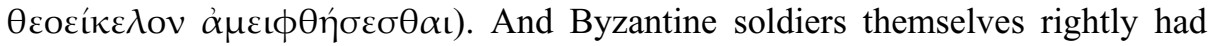
the reputation among all nations, the historian asseverates, of being "matricidal

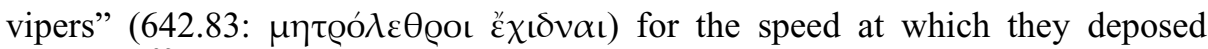
emperors. $^{92}$

The single amphibian is the frog, which is chosen solely for its colour, the protosebastos Alexios using "frog-coloured ink" (230.79: $\beta \alpha \tau \varrho \alpha ́ \chi \varepsilon เ о \nu ~ \beta \alpha ́ \mu \mu \alpha)$,

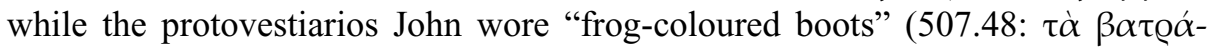

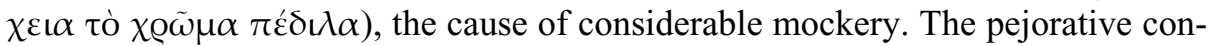
notation of this colour, already noted by Kazhdan and Franklin, ${ }^{93}$ is made even clearer by a third passage in which the entire body of a poisoned bull "turned

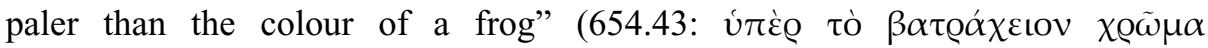
$\dot{\varepsilon} \chi \lambda \hat{\omega} \varrho \iota \zeta \varepsilon)$.

In the class Insecta Choniates favours the two archetypical gatherers and workers, the ant and the bee.

Ants are used in two ways: as an image of swarming masses and as diggers. For the first the historian emphasizes the huge crowd of citizens that escorted him and his family from his home at the fall of Constantinople in 1204 by asseverating that they were all "like an assembly of ants as they passed through the streets"

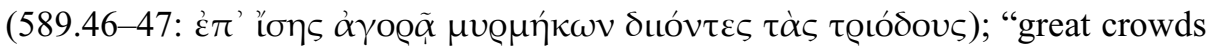
streamed" to listen to the buffoonish prophet Basilakios "more than worker-ants

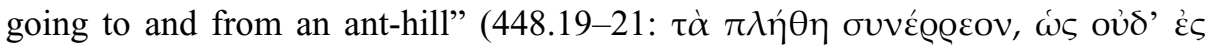

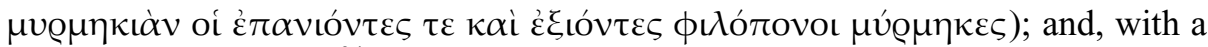
recollection of Homer, ${ }^{94}$ Cuman troops were "more numerous than armies of ants

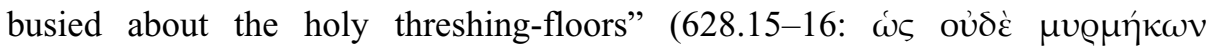

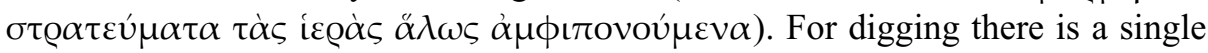

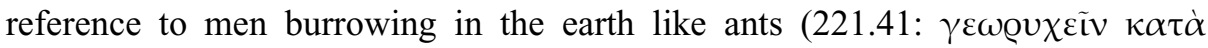
$\mu v ́ \varrho \mu \eta \kappa \alpha \varsigma)$ to make shelters from the winds.

92 For the repentant evil-doer compared with potential prey avoiding a snake (113.82-84), Latin inhumanity compared with "death-bringing viper or deadly heel-menacing snake" (301.4) and the wife of Alexios Axuch pleading more grievously than serpents (145.2) see above, 238 (bis) and 247 respectively. A final passage probably refers to a snake's venom: Rukn al-Din's aggressive and arrogant missives were "like deadly venom poured and scattered indiscriminately"

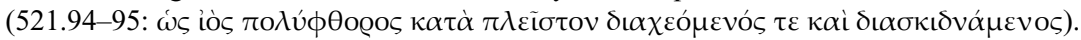

93 Studies on Byzantine Literature (see n. 4), 262-263. In Choniates' source (Aristoph. Eq. 523) it has already been used in mockery.

94 Il. 5.499. 
The most original image of bees has already been seen. ${ }^{95}$ The insect appears first in another Homeric reminiscence ${ }^{96}$ when courtiers early in Manuel's reign "were like a swarm of bees buzzing as they flew out of a hollow rock" (59.18-19:

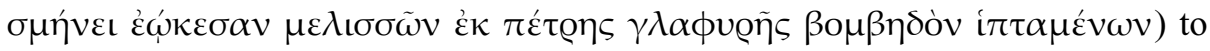
receive imperial largesse (and Choniates uses the very next line of the same quotation $^{97}$ to make Cumans "rival bees among vernal flowers" [628.13:

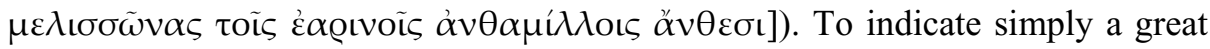
crowd "the people gathered together like swarms of bees leaving their hives"

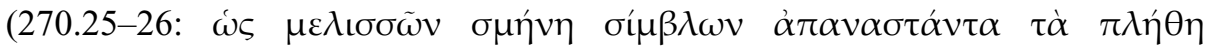

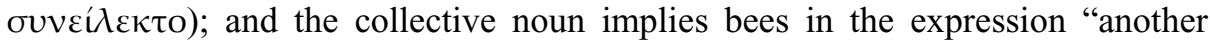

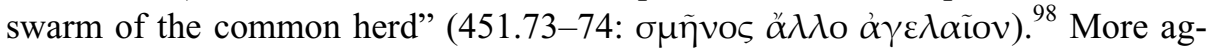
gressively the Psalmist's "they encompassed me about like bees a honeycomb"

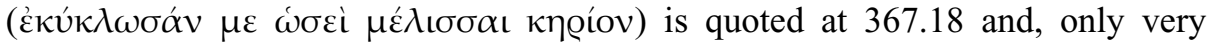
slightly altered, at 434.19, while Cumans, again, are compared to bees when "it was like seeing swarms of bees issuing forth from their hives and wasps flying

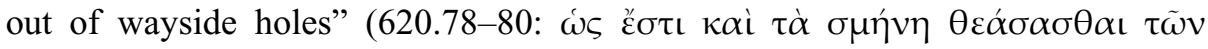

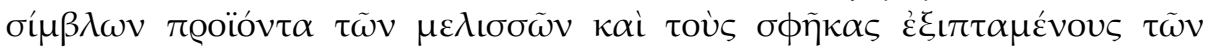
$\left.\dot{\varepsilon} \operatorname{vo\delta i}^{\prime} \omega \nu \chi \eta \emptyset \alpha \mu \tilde{\omega} v\right)$. Drones are specified for the Philadelphians paying court to Andronikos, since "they buzzed like drones around the streets and the palace"

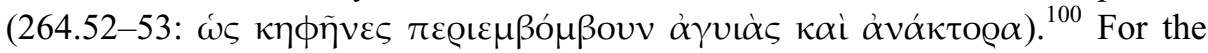
pestering by a single individual Aesop (Fab. 267) is employed for Constantine Mesopotamites who "was simply a bumble-bee or a mosquito buzzing around the

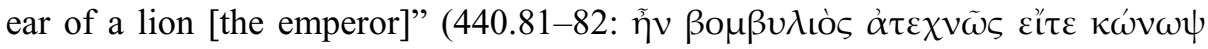

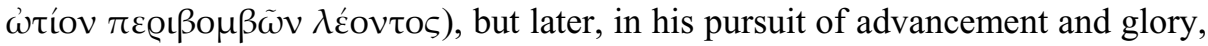
the courtier "escaped detection like the mosquito in the fable when it was battling with a lion but was caught by a fine spider's web" (491.7-8: ع้ $\lambda \alpha \theta \varepsilon v$ ws ó

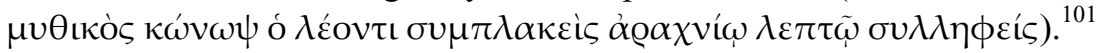

Mesopotamites is compared also with the famous flea in Socrates' "thinkery"102 when "all those onto whose head he had leapt like the flea in the comedy and whose jaw he had all but struck as if they were slaves" (491.12-14:

95 227.23-25, above, 240.

96 Il. $2.87-88$.

97 Ibid. 2.89. This directly precedes the comparison with ants just quoted (above, 253).

98 The adjective had long since become a dead metaphor.

99 Ps. 117.12.

100 Having in the same sentence just compared them to crows and eaglets, Choniates immediately continues with a zoologically most inapt addition: "just as is the custom of the lazy and those who grow a forked tongue in their mouths".

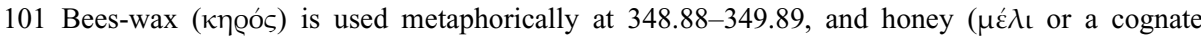
word) for sweetness of tongue or words at $63.16-17 ; 248.68 ; 352.9$ and $606.6-7$, and in other metaphorical contexts at 112.46 and 585.45 .

102 Aristoph., Nub. 144-147. 


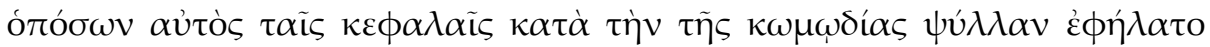

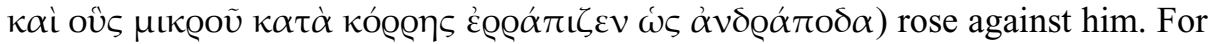
muscid imagery he has Andronikos "brooding over the words [of an oath] just as

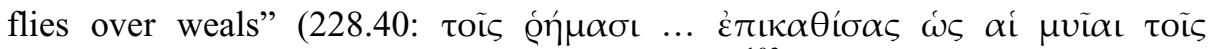
$\mu \omega \lambda \omega \psi \iota)$; and elsewhere he expands on Homer ${ }^{103}$ when the common citizens ignore Andronikos' pitiable death and concern themselves with their own doings "gathering together like tribes of flies that fly around springtime's milk-pails and take gulps from the brimming drinking-cups of ivy-wood" (349.18-19: $\kappa \alpha \tau$ '

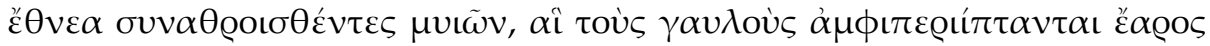

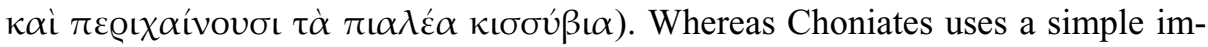
age of locusts for the Patzinaks plundering Thrace and "obliterating everything underfoot more thoroughly than a swarm of locusts" (13.40-41: $\tau \dot{\alpha} \dot{\varepsilon} v$ rooiv

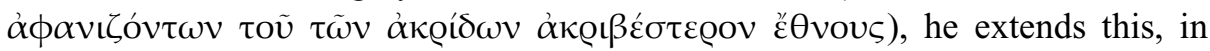
part inappositely, by adapting Iliad 21.12-14 for Andronikos' opponents who "brought in an alien and foreign army and acted exactly like a swarm of locusts

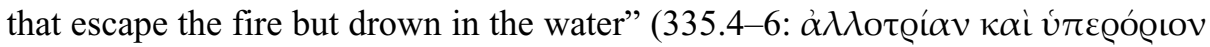

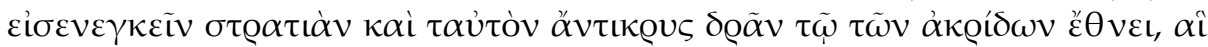

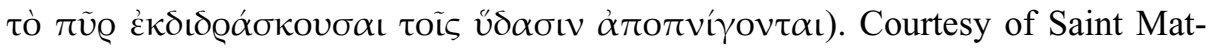
thew (6.19-20) any donation given to Andronikos was rejected "being under suspicion like a moth ... or some other corrupting agency that destroys what

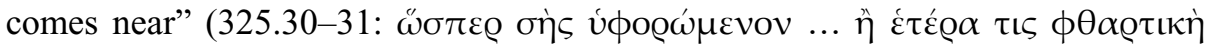

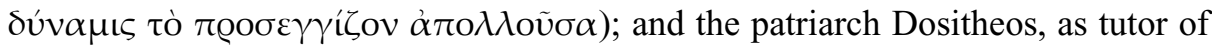
Isaac II, is described as "entering unobserved like a moth and corroding his na-

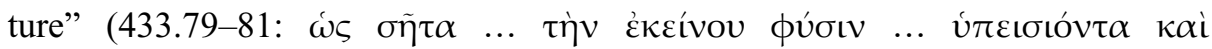

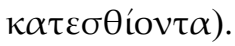

Three other insects make only brief appearances. The historian criticizes Alexios III for clinging to his palace "like a larva stuffing itself into its chrysalis"

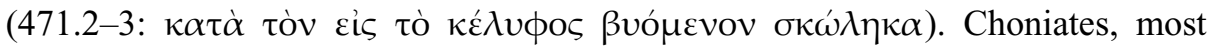
unusually, acknowledges his debt to Job (4.11) for an image of the neuropterous predator of the family Myrmeleontidae known as an ant-lion when men celebrated the fall of Mesopotamites as if "the gluttonous ant-lion had perished"

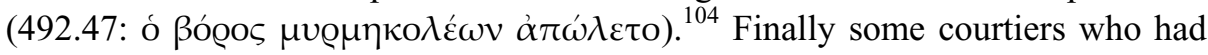
fallen from power with the rise of Mesopotamites "were dimmed like glowworms when the day breaks into a smile" (485.5-6: $\kappa \alpha \tau \dot{\alpha} \pi v \gamma o \lambda \alpha \mu \pi i \delta \alpha \varsigma$

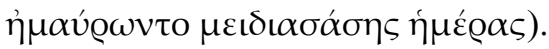

The single arachnid is the generic spider, brought in by Choniates only for its web, for which he finds three different words: Andronikos swept away plots "like

103 Il. $2.469-471$.

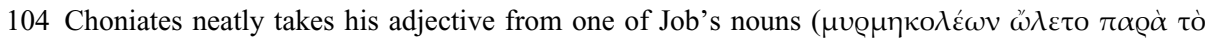

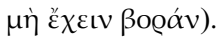




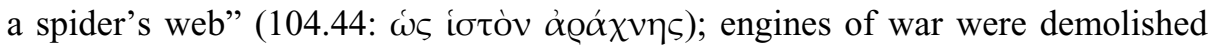

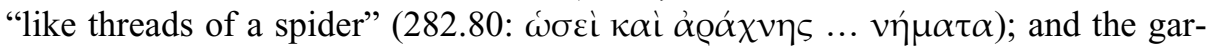
ment of a statue of Helen was "more delicate than spiders' webs" (652.66:

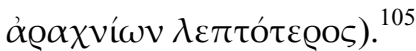

Finally, one of Choniates' most effective similes employs a hybrid animal, the mythical Chimaira, which consisted of a lion, a goat and a snake. "Upon the fall of famed Thessaloniki there occurred ... a separation of the Sicilian army; one could say that like the mythical Chimaira a well-balanced force previously united was divided, and its forepart, the most powerful, like a lion immediately hastened towards the queen of cities, its middle grazed the areas around Amphipolis and Serrai and the remainder, the fleet, trailing along in the waters like a snake, kept watch over the metropolis of the Thessalians" (319.45-51: $\dot{\varepsilon} \pi \varepsilon \dot{i} \delta \dot{\varepsilon}$

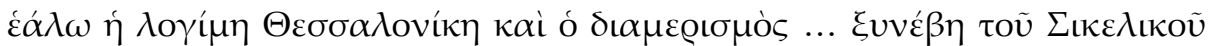

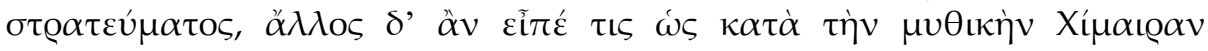

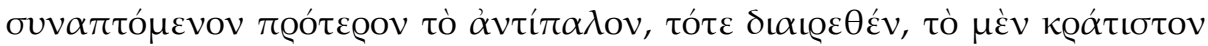

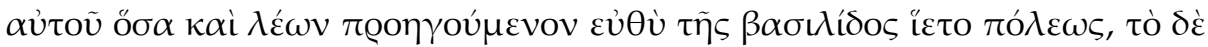

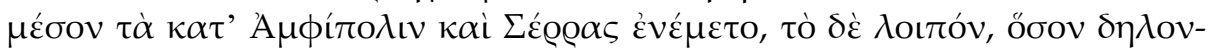

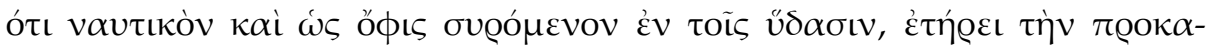

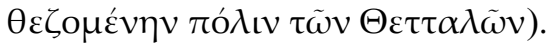

This survey has demonstrated both Choniates' huge range of subjects for imagery in the two spheres of plants and animals and also his quest for Selbstvariation in meticulously avoiding the use of the same vocabulary when repeating an image. This trait is one rarely favoured today, but it was beloved by Byzantine writers who often excelled at it. How deliberate it was is evident from Choniates' success in so long a work as his History, for which checking earlier wording was necessarily rendered hard by both a hand-written text and the lack of pagenumbering. ${ }^{106}$

Kazhdan and Franklin emphasize ${ }^{107}$ that, in contrast to that of Nikephoros Gregoras, Choniates' imagery is almost invariably gloomy. ${ }^{108}$ This is of course true, but hardly surprising since his history treats of events from late summer 1118 to autumn 1207, a period of worsening problems in the Empire culminating in the sacks of Thessaloniki and Constantinople by "the sanctified bandits", a period of whose principal events and actors modern historians find little good to say, a period in which Choniates witnessed the sack and pillage of the capital with the destruction of so many works of ancient art and in which he himself lost both

105 For the mosquito of fable escaping the lion but caught in the spider's web see above, 254.

106 On the other hand we must remember that technological dependence (and increasing literacy) militates against memory.

107 Studies on Byzantine Literature (see n. 4), 257-271.

108 Ibid., 271. 
home and high rank. But Choniates can use imagery to praise when the subject justifies it. The outstanding example is Eustathios, archbishop of Thessaloniki, whose image as a mother-bird gathering her chicks beneath her wings has already been seen, ${ }^{109}$ and at whose words Latins would become gentler "like an inflamed

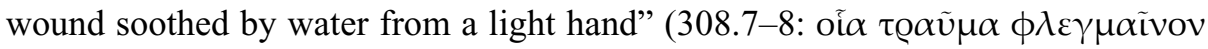

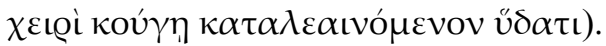

One thing not evident from this survey of the vegetal and animal worlds alone is that despite numerous images drawn from the Bible (especially the Old Testament), Choniates is in fact more dependent upon Classical literature. Here his comparisons are drawn almost exclusively from the Iliad and, in huge numbers, from mythology without any specific source; while there are also many comparisons made with historical persons and events. Imagery from quotidian life has a much greater percentage of examples of his own devising than that from the vegetal and animal worlds.

Another thing that the survey obscures is the historian's inordinate love for piling on images. Style is, of course, subjective, and, although this particular aspect of Choniates' composition is found in many other Byzantine authors, unlike the desire for Selbstvariation, there are considerable differences between writers. Psellos, for instance, prefers to expand an image, and if he does use different images he attempts to make them compatible. ${ }^{110}$ Typical of Choniates, on the other hand, are his description of Mesopotamites once looked down on but now regarded as "the horn of Amaltheia, ... multifarious mixing-bowl of virtues, all the herbage of Job's field, ... the genuine pearl of Peroz always hanging from the emperor's ears, ... Artemon the notorious, Argos the many-eyed, Briareus the

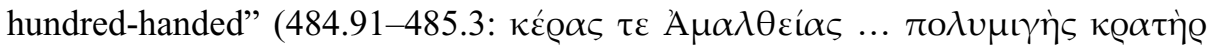

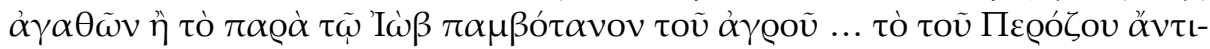

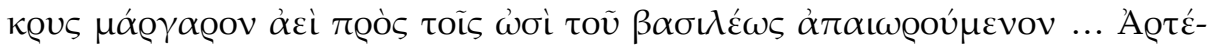

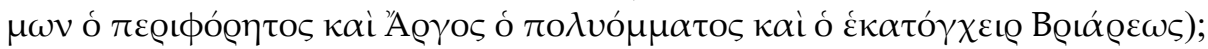
or of those who exulted at his toppling "as though the fall of hostile nations had been successfully accomplished or a wild beast which is hard to capture and had desolated cities and destroyed their inhabitants, changing its colours like they say Libyan beasts do, had been taken, or the serpent that Iob could not catch had been seized or the gluttonous ant-lion destroyed or the many-tassled and fearsome aegis had been hurled into the nether abyss and torn asunder" (492.43-48: $\omega \varsigma$

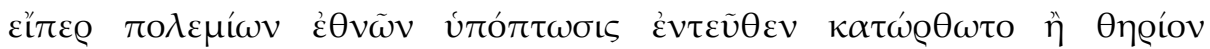

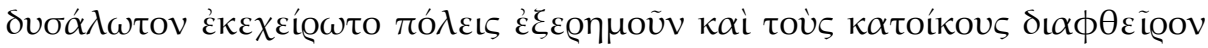

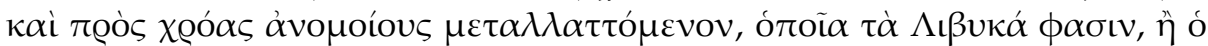

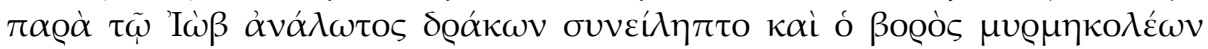

109 Above, 246.

110 Many examples are given in Littlewood, Imagery (see n. 2). 


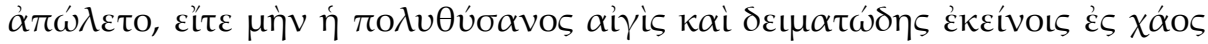

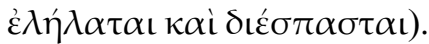

Not evident either is the quantity of similes and comparisons, which is far greater per page than in Psellos' Chronographia. Of this Choniates gives readers due warning in the disclaimer of his preface when in asseverating that History eschews both "rhetorical cleverness and poetic story-telling" (3.49-50: $\dot{\eta} \tau \varepsilon$

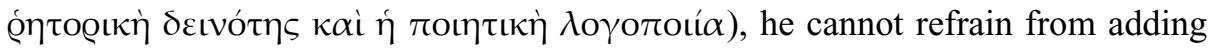
that even when treated with dignity she is "desirous of being put before diggers and smiths covered in much soot and of being familiar to those who gaze at ...

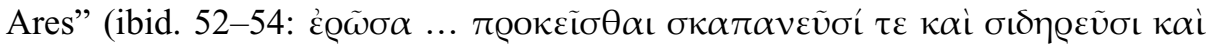

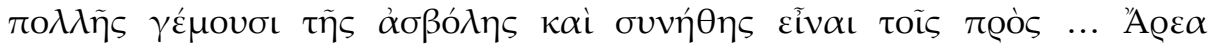
$\beta \lambda \varepsilon ́ \pi 0 v \sigma \iota)$, and that while she rejoices in very graceful phraseology "she yearns to be adorned with the pure and simple mantle of words" (ibid. 56-57: tò фó @os

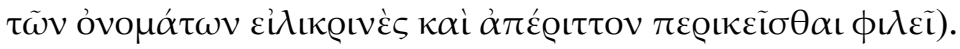

